\title{
Antidiabetic Potency, Antioxidant Effects, and Mode of Actions of Citrus reticulata Fruit Peel Hydroethanolic Extract, Hesperidin, and Quercetin in Nicotinamide/Streptozotocin-Induced Wistar Diabetic Rats
}

\author{
Alaa M. Ali, ${ }^{1}$ Mohamed Abdel Gabbar $\mathbb{D}^{2},{ }^{2}$ Sanaa M. Abdel-Twab, ${ }^{1}$ Eman M. Fahmy, \\ Hossam Ebaid $\odot{ }^{4,5}$ Ibrahim M. Alhazza, ${ }^{4}$ and Osama M. Ahmed $\oplus^{1}$ \\ ${ }^{1}$ Physiology Division, Zoology Department, Faculty of Science, Beni-Suef University, Beni-Suef, P. O. Box 62521, Egypt \\ ${ }^{2}$ Biochemistry Department, Faculty of Science, Beni-Suef University, Beni-Suef, P. O. Box 62521, Egypt \\ ${ }^{3}$ Department of Internal Medicine, Faculty of Medicine, Helwan University, Egypt \\ ${ }^{4}$ Department of Zoology, College of Science, King Saud University, P. O. Box 62521, Riyadh 11451, Saudi Arabia \\ ${ }^{5}$ Department of Zoology, Faculty of Science, El-Minia University, P.O. Box 61519, Minya, Egypt
}

Correspondence should be addressed to Osama M. Ahmed; osama.ahmed@science.bsu.edu.eg

Received 1 January 2020; Revised 12 May 2020; Accepted 23 May 2020; Published 22 June 2020

Academic Editor: Ana Lloret

Copyright (c) 2020 Alaa M. Ali et al. This is an open access article distributed under the Creative Commons Attribution License, which permits unrestricted use, distribution, and reproduction in any medium, provided the original work is properly cited.

\begin{abstract}
This study is aimed at assessing the antihyperglycemic, antihyperlipidemic, and antioxidant effects of Citrus reticulata (C. reticulata) fruit peel hydroethanolic extract and two flavonoids, hesperidin and quercetin, in nicotinamide (NA)/streptozotocin(STZ-) induced type 2 diabetic rats. In addition, GC-MS and HPLC-MS analyses of the extract were performed and the results indicated the presence of multiple flavonoids including hesperidin, quercetin, naringin, and polymethoxylated flavones (nobiletin and tangeretin). To achieve the aim of the study, diabetic rats with NA/STZ-induced T2DM were orally treated with C. reticulata fruit peel hydroethanolic extract, hesperidin, and quercetin at a dose of $100 \mathrm{mg} / \mathrm{kg}$ b.w./day for four weeks. The treatments with C. reticulata fruit peel extract, hesperidin, and quercetin significantly ameliorated the impaired oral glucose tolerance; the elevated serum fructosamine level; the diminished serum insulin and C-peptide levels; the altered HOMA-IR, HOMA-IS, and HOMA- $\beta$ cell function; the decreased liver glycogen content; the increased liver glucose-6-phosphatase and glycogen phosphorylase activities; the deleteriously affected serum lipid profile; the elevated serum AST and ALT activities; and the raised serum creatinine and urea levels in the diabetic rats. The treatments also produced remarkable improvement in the antioxidant defense system manifested by a decrease in the elevated liver lipid peroxidation and an increase in the lowered glutathione content and GPx, GST, and SOD activities. Furthermore, the three treatments enhanced the mRNA expression of GLUT-4 and the insulin receptor $\beta$-subunit, but only quercetin produced a significant increase in the expression of adiponectin in adipose tissue of diabetic rats. In conclusion, C. reticulata fruit peel hydroethanolic extract, hesperidin, and quercetin have potent antidiabetic effects which may be mediated through their insulinotropic effects and insulin-sensitizing actions. In addition, the alleviation of the antioxidant defense system by the extract, hesperidin, and naringin may have an important action to enhance the antidiabetic actions and to improve liver and kidney functions in NA/STZ-induced diabetic rats.
\end{abstract}

\section{Introduction}

Diabetes mellitus (DM), one of the most common diseases in the world, results from impairments in insulin secretion and/or insulin action leading to disturbances in the metabolism of carbohydrates, lipids, and proteins $[1,2]$. The
American Diabetes Association (ADA) has classified DM into type $1 \mathrm{DM}$ (T1DM), type $2 \mathrm{DM}$ (T2DM), gestational DM (GDM), and many other specific types of diabetes [3]. T2DM is much more prevalent in humans than T1DM and is responsible for $90 \%$ of DM incidence $[4,5]$. The main reasons for T2DM are impaired tissue insulin sensitivity and 
insulin resistance which was coupled to pancreatic $\beta$-cell dysfunction [6-8]. Many experimental animal models of T2DM were applied by several publications to validate the use of new therapies and to elucidate the underlying molecular mechanism(s) of action of the tested drugs $[9,10]$.

Nicotinamide (NA)/streptozotocin- (STZ-) induced DM is the most commonly used animal model of T2DM in rats. STZ, an antibiotic drug formed by Streptomyces achromogenes, has damaging effects on the $\beta$-cells in the islets of Langerhans [11-13]. Many reports stated that the damaging effect of STZ on $\beta$-cells of pancreatic islets is caused by the stimulation of oxidative stress and suppression of antioxidant defense [14-16]. Furthermore, the intracellular biotransformation of STZ results in the production of nitric oxide (NO) which speeds up the formation of DNA strand breaks, leading to $\beta$-cells' necrosis [17]. NA injection before STZ in this DM-induced model, on the other hand, partially counteracts the destructive effect of STZ on $\beta$-cells, and it leads to the loss of the early phase of glucose stimulation of insulin secretion which is a feature of T2DM [18-20]. It was also proven by many investigators that in NA/STZinduced DM, there are both impairment in insulin secretion and insulin resistance, which is a characteristic feature of T2DM [21-23].

The search for suitable antihyperglycemic agents from natural sources has been focused on plants applied in traditional medicines partly because they have lower side effects than the currently used conventional drugs [24]. Recently, there is an increased interest in the medical benefits of flavonoids because their supplementation seems to be accompanied by reduced risks for certain severe maladies and increased survival as stated by previous publications [25-27]. Citrus fruit peels, i.e., the outer layers of many fruits including lemons, oranges, mandarins, and grapefruits, have been demonstrated to be rich in flavonoid content [27-30]. Flavonoids found in citrus fruits were mainly allocated to three classes: flavanones, flavones, and flavonols [31].

Citrus reticulata (C. reticulata) or tangerine fruit peels have been shown to contain high concentrations of three flavanones: hesperidin, naringin, and narirutin [32]. Citrus peel also contains good quantities of flavonol and quercetin [33]. Hesperidin, a glycosylated flavanone of hesperetin, has been reported by Constantin et al. [34] and Parhiz et al. [35] to decrease intestinal glucose absorption and inhibit the gluconeogenic pathways, thereby leading to antihyperglycemic actions in diabetic human beings. Quercetin, a principal flavonol found in citrus fruits especially in fruit peels, was found to have antidiabetic actions in diabetic animal models at doses of 10, 25, and $50 \mathrm{mg} / \mathrm{kilogram}$ body weight (kg b.w.) [36]. It is a glycone of rutin, and it is a parent compound of a number of various flavonoids $[37,38]$. Although the antidiabetic effects of hesperidin and quercetin were reported by some publications, the mechanisms of their antidiabetic actions are not fully elucidated. In addition, further investigations are needed to assess their comparative effects with the crude extract of C. reticulata fruit peel.

Therefore, the present study was conducted to assess the comparative antihyperglycemic, antihyperlipidemic, and antioxidant effects of $C$. reticulata fruit peel hydroethanolic extract, hesperidin, and quercetin in NA/STZ-induced DM in Wistar rats and to suggest their mechanisms of action.

\section{Materials and Methods}

2.1. Experimental Animals. Adult male rats of Wistar strain weighing about 130-150 g and aged 10-12 weeks were used in the present experimental research work. The animals were supplied from the animal house of the National Research Center (NRC), El-Tahrir Street, Dokki, Giza, Egypt. They were maintained under strict care for about 10 days before the start of the experiment to exclude any intercurrent infection. The rats were housed in clean polypropylene cages (six rats/cage) with a well-aerated standard stainless steel frame and wood mulch at the bottom of cage. The rats were maintained under normal controlled atmospheric temperature $\left(25 \pm 5^{\circ} \mathrm{C}\right)$, humidity $(55 \pm 5.6)$, and daily normal 12 -hour (hr) light/dark cycle. Moreover, they had free access to water and were provided daily with standard pelleted chow diet ad libitum. All animal procedures were in accordance with the guidelines and recommendations of the Experimental Animal Ethics Committee for Use and Care of Animals, Faculty of Science, Beni-Suef University, Egypt (ethical approval number is BSU/FS/2015/14). All instructions were followed, and all precautions were considered to minimize discomfort, distress, and pain of rats under investigations.

2.2. Drugs and Chemicals. STZ (2-deoxy-2-(3-methyl-3nitrosoureido)-D-glycopyranoside), NA, hesperidin, and quercetin were obtained from Sigma-Aldrich Chemical Company, St. Louis, MO, USA. NA, hesperidin, and quercetin were kept at $2-4^{\circ} \mathrm{C}$, while STZ was stored at $-20^{\circ} \mathrm{C}$. All other used chemicals were of analytical grade and were commercially obtained.

2.3. Extract Preparation of C. reticulata Fruit Peel. C. reticulata or tangerine fruits were purchased from the local market at Beni-Suef Governorate, Egypt. The purchased fruits were manually flaked and were cleaned by washing with running water till completely clean. The washed peels were then dried in a good aerated area. Then, the dried peels were ground to a powder by an electric mortar. The finely obtained powder $(0.5 \mathrm{~kg})$ was drenched in $70 \%$ ethanol for 3 days. The mixture was filtered by using a Whatman No. 2 filter paper for removal of peel particles. The water and ethanol were vaporized by a Rotavapor to obtain a semisolid viscous mass which was stored in dark bottles in a deep freezer at $-30^{\circ} \mathrm{C}$ pending its use for the treatment.

2.4. Gas Chromatography-Mass Spectrometry (GC-MS) Analysis. Chemical analysis of $C$. reticulata peel hydroethanolic extract was performed in the Central Laboratory of the Faculty of Postgraduate Studies for Advanced Sciences, Beni-Suef University, Egypt, by using the Gas Chromatography (GC) System 7890A/5975C Inert Mass Spectrometry (MS) with a Triple Axis Detector, Agilent Technologies, Germany. The constituents were recognized by comparing their mass spectra with the spectra of derivatives in the Library Search Report (C:|Database|NIST11.L; C:|Database $\mid$ demo.l) as well as in the NIST08s, WILEY8, and FAME libraries. 
2.5. High-Performance Liquid Chromatography- (HPLC-) Mass Spectrometry (MS) Analysis. HPLC-MS analysis of $C$. reticulata fruit peel hydroethanolic extract was performed in the Central Laboratory of the Faculty of Postgraduate Studies for Advanced Sciences, Beni-Suef University, Egypt, by using the HPLC-MS system, 1260 Infinity, Agilent Technologies, Germany coupled with a Diode Array Detector (DAD). Standards including gallic acid, naringin, quercetin, hesperidin, nobiletin, and tangeretin were used to identify their peaks in the HPLC-MS chromatogram. The C. reticulata fruit peel hydroethanolic extract was dissolved in water: methanol $(80: 20 \mathrm{v} / \mathrm{v})$ at a concentration of $10 \mathrm{mg} / 3 \mathrm{ml}$ and filtered with a $0.45 \mu \mathrm{m}$ filter, before injection of $20 \mu \mathrm{l}$ into the HPLC system. Spectral UV data from all peaks were collected in the range of $240-400 \mathrm{~nm}$, and chromatograms were recorded at 340 and $270 \mathrm{~nm}$ according to the method of Negri et al. [39].

2.6. Induction of T2DM. Experimental T2DM was induced in male Wistar rats, fasted for 16 hours (hrs), by a single intraperitoneal (i.p.) injection of STZ at a dose level of $50 \mathrm{mg}$ STZ/kg b.w. (dissolved in citrate buffer of $\mathrm{pH} 4.5$ ), 15 minutes after the i.p. injection of $120 \mathrm{mg} \mathrm{NA} / \mathrm{kg}$ b.w. [40]. Ten days after NA/STZ injection, overnight-fasted rats were orally supplemented with glucose (3 g/kg b.w.) by oral gavage. After $2 \mathrm{hrs}$ of oral glucose administration, blood samples taken from the lateral tail vein were left to coagulate and then centrifuged. Thereafter, serum glucose level was detected. After screening of serum glucose levels, the rats which have serum glucose levels of $180-300 \mathrm{mg} / \mathrm{dl}$ after $2 \mathrm{hrs}$ of oral glucose loading were considered mildly diabetic and were included in the experiment. Rats with serum glucose levels outside this range were excluded.

2.7. Experimental Design. The rats included in the experiment were divided into five groups, each group comprising six rats as follows:

(1) Group 1 was regarded as the normal control group and received the equivalent volume of the vehicle, $1 \%$ carboxymethyl cellulose (CMC), by oral gavage daily for four weeks

(2) Group 2 was regarded as the diabetic control group and received the equivalent volume of $1 \% \mathrm{CMC}$ by oral gavage daily for four weeks

(3) Group 3 served as diabetic rats that were treated with C. reticulata fruit peel hydroethanolic extract at a dose level of $100 \mathrm{mg}$ in $5 \mathrm{ml} \mathrm{1 \%} \mathrm{CMC/kg} \mathrm{b.w./day}$ [41], by oral gavage, for four weeks

(4) Group 4 served as diabetic rats that were treated with hesperidin (Sigma-Aldrich Chemical Company, MO, USA), at a dose level of $100 \mathrm{mg}$ (dissolved in $5 \mathrm{ml} \mathrm{1 \%}$ $\mathrm{CMC} / \mathrm{kg}$ b.w./day, by oral gavage, for four weeks [42].

(5) Group 5 served as diabetic rats that were treated with quercetin (Sigma-Aldrich Chemical Company, MO, USA), at a dose level of $100 \mathrm{mg}$ (dissolved in
$5 \mathrm{ml} \mathrm{1 \%} \mathrm{CMC)/kg} \mathrm{b.w./day,} \mathrm{by} \mathrm{oral} \mathrm{gavage,} \mathrm{for} \mathrm{four}$ weeks [43].

Each week, the dose was adjusted according to the alterations in b.w. to stabilize the correct dose per kg b.w. of rats during the entire period of the experiment.

2.8. Blood and Tissue Sampling. At the day before decapitation, an oral glucose tolerance test (OGTT) was performed for all individual rats. Blood samples were withdrawn from the lateral tail veins of overnight-fasted rats at $30,60,90$, and 120 minutes following the oral glucose loading $(3 \mathrm{~g} / \mathrm{kg}$ b.w.), left to clot, and centrifuged at 4000 rounds per minute (rpm) for 15 minutes. After that, sera were quickly collected for the detection of serum glucose levels.

A day following OGTT, the overnight-fasted animals were anaesthetized by diethyl ether inhalation anaesthesia and blood samples were obtained from the jugular vein. Then, after decapitation by cervical dislocation, rats were dissected and liver, visceral adipose tissue, and pancreas were excised and perfused in saline. The blood from each rat was collected in gel and clot activator tubes and centrifuged at $4000 \mathrm{rpm}$ for 15 minutes. The obtained sera were stored in a deep freezer at $-30^{\circ} \mathrm{C}$ until they were used for biochemical detection. The liver was kept in a deep freezer at $-30^{\circ} \mathrm{C}$ pending its use for the determination of liver glycogen content and homogenization in saline $(2 \% w / v)$. Pieces of visceral adipose tissue $\left(3 \mathrm{~mm}^{3}\right)$ were kept in a deep freezer at $-70^{\circ} \mathrm{C}$ pending their use in RNA isolation and RT-PCR analysis. Pancreas from each rat was fixed in $10 \%$ neutral buffered formalin and transferred to the Pathology Department, National Cancer Institute (NCI), Cairo University, Cairo, Egypt, for processing, blocking in wax, sectioning, and staining with the trichrome PAS method.

2.9. Biochemical Assays. Serum glucose level was determined based on the method of Trinder [44] by a reagent kit obtained from Randox Laboratories, United Kingdom (UK). Serum fructosamine level was determined according to the method of Baker et al. [45]. Serum insulin and Cpeptide levels were determined by an ELISA kit obtained from Linco Research Inc., USA, according to the manufacturer's instruction. Homeostasis model assessment of insulin resistance (HOMA-IR), homeostasis model assessment of insulin sensitivity (HOMA-IS), and homeostasis model assessment of $\beta$-cell function (HOMA- $\beta$ cell function) were calculated according to the equations described by Mishra et al. [46] and Aref et al. [47]. The measurement of serum total cholesterol (TC) and HDL-cholesterol (HDL-C) levels was performed based on the publication of Allain et al. [48], using a reagent kit obtained from Randox Laboratories (UK). Serum triglyceride (TG) level was determined based on the method of Finley and Tietz [49]. Serum LDL-cholesterol (LDL-C) level was determined based on Friedewald et al.'s [50] formula ( $\mathrm{LDL}-\mathrm{C}=\mathrm{TC}-\mathrm{HDL}-\mathrm{C}-\mathrm{TG} / 5$ ). Serum vLDL-cholesterol (vLDL-C) was calculated based on Norbert's [51] formula (vLDL $-\mathrm{C}=\mathrm{TG} / 5$ ). FFA level in serum was estimated based on the publication of Duncombe [52]. Aspartate transaminase (AST) and alanine transaminase (ALT) activities 
in serum were measured, respectively, based on the publication of Gella et al. [53], by reagent kits delivered from Randox Laboratories (UK). Serum creatinine and urea levels were determined by using kits obtained from Biosystems S.A. (Spain) according to the methods of Fabiny and Ertingshausen [54] and Tabacco et al. [55], respectively.

Liver glycogen content was estimated based on the procedure of Seifter et al. [56]. Glucose-6-phosphatase (G-6-Pase) and glycogen phosphorylase activities in liver homogenates were assayed based on the procedures of Kabir and Begum [57] and Stalmans and Hers [58], respectively.

Liver lipid peroxidation (LPO) was estimated by malondialdehyde (MDA) detection based on the publication of Preuss et al. [59]. Liver glutathione (GSH) content was detected based on the publication of Beutler et al. [60]. Liver glutathione peroxidase (GPx) and glutathione-S-transferase (GST) activities were detected based on the procedures of Matkovics et al. [61] and Mannervik and Gutenberg [62], respectively. The enzyme SOD activity in liver was measured based to the procedure of Marklund and Marklund [63].

2.10. Histological Investigation. Pancreatic tissues fixed in $10 \%$ neutral buffered formalin were transferred to the Pathology Department, National Cancer Institute, Cairo University, Cairo, Egypt, for processing, which included embedding in paraffin wax, sectioning at $5 \mu \mathrm{m}$ thickness, and staining with a modified aldehyde fuchsin stain method according to Bancroft and Stevens [64].

2.11. RNA Isolation and RT-PCR Analysis. The total RNA was isolated from visceral adipose tissue by the GeneJET RNA Purification Kit obtained from Thermo Scientific Verso 1-Step RT-PCR ReddyMix Kit, Thermo Fisher Scientific Inc., USA according to the publications of Chomzynski and Sacchi [65] and Boom et al. [66]. The levels of isolated RNA were determined and quantified using an ultraviolet (UV) spectrophotometer and taking the absorbances at optical densities (OD) of $260 \mathrm{~nm}$ and $280 \mathrm{~nm}$. RNA was quantified and qualified based on Finley and Tietz's [49] formula $(\mathrm{RNA}(\mu \mathrm{g} / \mu \mathrm{l})=\mathrm{OD}$ at $260 \mathrm{~nm} \times$ dilution $\times 40 \mu \mathrm{g} / \mathrm{ml} / 1000)$.

For each extracted RNA sample, the ratio was between $\mathrm{OD}$ at $260 \mathrm{~nm}$ and $\mathrm{OD}$ at $280 \mathrm{~nm}$ and the ratio ranged between 1.7 and 2.0 to ensure the high purity of extracted RNA. Thermo Scientific Verso 1-Step RT-PCR ReddyMix was applied for the synthesis of cloned DNA (cDNA) which, in turn, was amplified by using specific forward and reverse primers by 32 Techne thermal cyclers. The primer pair sequences are as follows: GLUT-4-forward: 5 ' GCTGTG CCATCTTGATGACGG $3^{\prime}$ and reverse: $5^{\prime}$ TGAAGAAGC CAAGCAGGAGGAC $3^{\prime}[1]$; insulin receptor $\beta$-subunit (IR $\beta$ )-forward: $5^{\prime}$ CTGGAGAACTGCTCGGTCATT $3^{\prime}$ and reverse: 5' GGCCATAGACACGGAAAAGAAG $3^{\prime}$ [67]; adiponectin-forward: 5' AATCCTGCCCAGTCAT GAAG $3^{\prime}$ and reverse: $5^{\prime}$ TCTCCAGGAGTGCCATCTCT $\left.3^{\prime}[68,69]\right)$; and $\beta$-actin-forward: $5^{\prime}$ TCACCCTGAAG TACCCCATGGAG $3^{\prime}$ and reverse: $5^{\prime}$ TTGGCCTTGGG GTTCAGGGGG 3' [70]).
2.12. Statistical Analysis. The obtained individual data were statistically analyzed by one-way analysis of variance (ANOVA) using the PC-STAT program, University of Georgia, followed by the Least Significance Difference (LSD) test to compare various groups with each other [71]. $F$-probability for the detected parameter represents the general effects between groups. All data are represented as mean \pm SEM, and significant changes were calculated at $p<$ 0.05 and $p<0.01$ for LSD and at $p<0.05, p<0.01$, and $p<$ 0.01 for $F$-probabilities.

\section{Results}

3.1. GC-MS Analysis of C. reticulata Peel Hydroethanolic Extract. The GC-MS analysis (Table 1 and Figure 1) indicated the presence multiple phytochemicals. The main constituents and groups which have a concentration of more than $1 \%$ of the total include $4 \mathrm{H}$-pyran-4-one (a cyclic nucleus in the chemical structure of quercetin, naringin, hesperetin, nobiletin tangeretin, etc.), 2,3-dihydro-3,5-dihydroxy-6-methyl-; 5-hydroxymethylfurfural; 4-hexen-3-one, 4,5-dimethyl; phenol, 4-ethyl-; benzaldehyde, 4-hydroxy-; benzaldehyde, 2-hydroxy-; 3,3', $4^{\prime}, 5,5^{\prime}, 7,8$-heptamethoxyflavone; 4h-1-benzopyran-4-one, 2-(3,4-dimethoxyphenyl)5,6,7-trimethoxy-; and $\beta$-D-glucopyranose, 4 -O- $\beta$-D-galactopyranosyl-; n-hexadecanoic acid; tridecanoic acid; 9,12octadecadienoic acid (Z,Z)-; (Z)6,(Z)9-pentadecadien-1-ol; 9,12,15-octadecatrien-1-ol, (Z,Z,Z)-; 9,12,15-octadecatrien1-ol, (Z,Z,Z)-; 9-octadecenamide, (Z)-.

4H-Pyran-4-one, 2,3-dihydro-3,5-dihydroxy-6-methyl-; 5-hydroxymethylfurfural; 4-hexen-3-one, 4,5-dimethyl-; 4h-1-benzopyran-4-one, 2-(3,4-dimethoxyphenyl)-5,6,7-trimethoxy-; and $\beta$-D-glucopyranose, 4 -O- $\beta$-D-galactopyranosyl- have the highest percent of the total.

3.2. HPLC-MS Analysis of Navel Orange Peel Hydroethanolic Extract. HPLC-MS analysis indicated in Figures 2(a) and 2(b) revealed the presence of gallic acid, naringin, quercetin, hesperidin, nobiletin, and tangeretin at abundances (percent of total) of $7.152 \%, 13.219 \%, 3.042 \%, 32.960 \%, 8.237 \%$, and $2.776 \%$ at a signal of $270 \mathrm{~nm}$ and $1.036 \%, 4.403 \%, 3.018 \%$, $45.018 \%, 10.095 \%$, and $3.688 \%$ at a signal of $340 \mathrm{~nm}$, respectively. Accordingly, hesperidin, naringin, and nobiletin were the most abundant.

3.3. Oral Glucose Tolerance Test (OGTT). Figure 3 showed that the normal animals had a fasting serum glucose level which was significantly lower than that of the diabetic ones. Serum glucose level reached its peak value after 60 minutes following glucose intake ( $3 \mathrm{~g} / \mathrm{kg}$ b.w.) and began to decrease during the next 60 minutes to reach its minimum level at 2 hrs of oral glucose loading. On the other hand, the serum glucose level of NA/STZ diabetic control rats also reached its maximum after 60 minutes of oral glucose loading. Then, this value began to decline but in a slower rate and was still higher as compared to the normal one. Furthermore, the diabetic control rats exhibited a highly significant increase in serum glucose level $(p<0.01$; LSD) as compared to normal ones at all points of OGTT. After 4 weeks of treatment, $C$. 
TABLe 1: Chemical composition of C. reticulata hydroethanolic extract as detected by GC-MS analysis.

\begin{tabular}{|c|c|c|c|}
\hline Number & Retention time & Compound (from the central Library Search Report) & Area \% (higher than $1 \%$ ) \\
\hline 1 & 15.282 & (i) No matches in library & $3.50 \%$ \\
\hline 2 & 16.556 & (i) 4H-Pyran-4-one, 2,3-dihydro-3,5-dihydroxy-6-methyl- & $3.55 \%$ \\
\hline 3 & 17.906 & (i) No matches in library & $1.13 \%$ \\
\hline 4 & 18.080 & (i) No matches in library & $2.14 \%$ \\
\hline 5 & 18.579 & $\begin{array}{l}\text { (i) 5-Hydroxymethylfurfural } \\
\text { (ii) 4-Hexen-3-one, 4,5-dimethyl- }\end{array}$ & $17.74 \%$ \\
\hline 6 & 18.981 & (i) No matches in library & $1.57 \%$ \\
\hline 7 & 19.803 & (i) No matches in library & $2.65 \%$ \\
\hline 8 & 20.241 & (i) No matches in library & $1.84 \%$ \\
\hline 9 & 21.329 & $\begin{array}{l}\text { (i) Phenol, 4-ethyl- } \\
\text { (ii) Benzaldehyde, 4-hydroxy- } \\
\text { (iii) Benzaldehyde, 2-hydroxy- }\end{array}$ & $1.00 \%$ \\
\hline 10 & 27.047 & (i) $3,3^{\prime}, 4^{\prime}, 5,5^{\prime}, 7,8$-heptamethoxyflavone & $1.78 \%$ \\
\hline 11 & 27.356 & $\begin{array}{l}\text { (i) 4h-1-benzopyran-4-one, } 2 \text {-(3,4-dimethoxyphenyl)-5,6,7-trimethoxy- } \\
\text { (ii) } \beta \text {-D-Glucopyranose, } 4 \text {-O- } \beta \text {-D-galactopyranosyl- }\end{array}$ & 3.00 \\
\hline 12 & 29.940 & (i) Dodecane & $1.29 \%$ \\
\hline 13 & 32.898 & $\begin{array}{l}\text { (i) n-Hexadecanoic acid } \\
\text { (ii) Tridecanoic acid }\end{array}$ & $2.88 \%$ \\
\hline 14 & 34.964 & (i) 9,12-Octadecadienoic acid (Z,Z)- & $2.37 \%$ \\
\hline 15 & 35.033 & $\begin{array}{l}\text { (i) 9,12,15-Octadecatrienoic acid, (Z,Z,Z)- } \\
\text { (ii) (Z)6,(Z)9-Pentadecadien-1-ol } \\
\text { (iii) 9,12,15-Octadecatrien-1-ol, (Z,Z,Z)- }\end{array}$ & $2.46 \%$ \\
\hline 16 & 37.253 & (i) 9-Octadecenamide, (Z)- & $1.34 \%$ \\
\hline
\end{tabular}

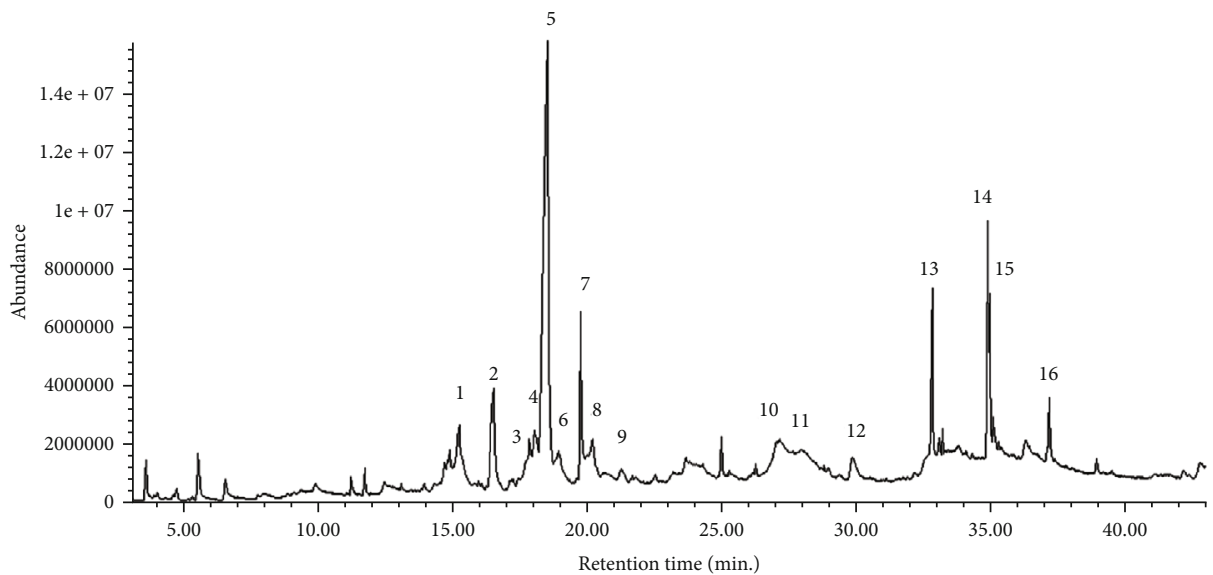

FIGURE 1: GC-MS chromatogram of C. reticulata fruit peel hydroethanolic extract.

reticulata hydroethanolic peel extract, hesperidin, and quercetin produced a highly significant $(p<0.01$; LSD) hypoglycemic effect on fasting serum glucose level of diabetic treated rats as compared to the nontreated diabetic group. The present data also revealed that hesperidin was the most potent in decreasing the elevated serum glucose levels of NA/STZ-induced diabetic rats at fasting state, while C. reticulata hydroethanolic peel extract was the most potent at $30,60,90$, and 120 minutes after oral glucose administration. As the one-way ANOVA test was applied on OGTT of normal, diabetic control, and diabetic treated rats, the effect between groups on OGTT was very highly significant $(p<0.001 ; F$-probability).

3.4. Effect on Serum Fructosamine Level. As observed in Figure 4, serum fructosamine level exhibited a significant elevation $(p<0.01$; LSD) in NA/STZ-induced diabetic animals. The treatment of diabetic rats with $C$. reticulata fruit peel extract, hesperidin, and quercetin induced a significant improvement of the elevated serum fructosamine level recording percentage decreases of $-62.11 \%,-55.74 \%$, and $-57.48 \%$, respectively, as compared with the diabetic control rats. 


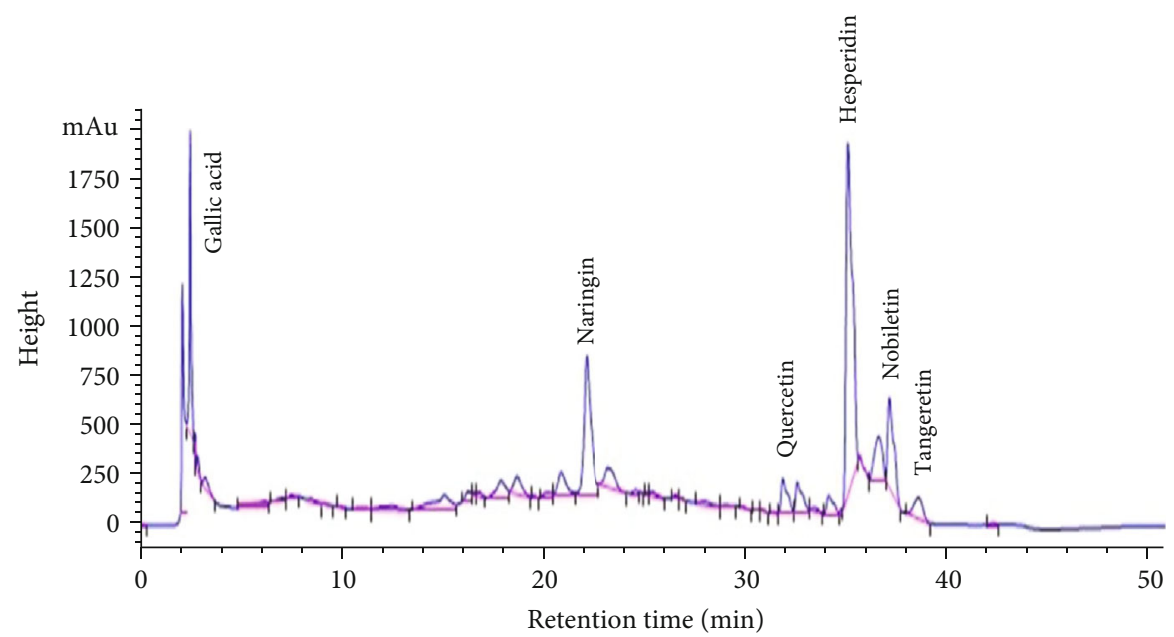

(a)

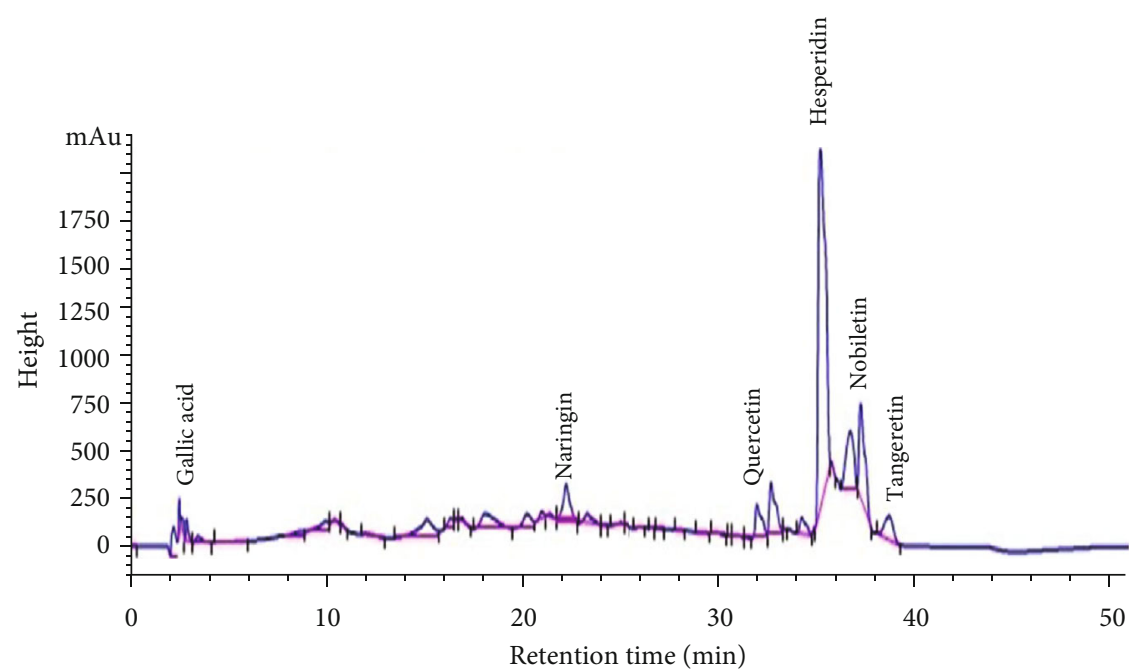

(b)

FIGURE 2: HPLC-MS fingerprint of C. reticulata fruit peel hydroethanolic extract at $270 \mathrm{~nm}$ (a) and at $340 \mathrm{~nm}$ (b) indicating the presence of gallic acid, naringin, quercetin, hesperidin, nobiletin, and tangeretin at abundances (percent of total) of 7.152\%, 13.219\%, 3.042\%, 32.960\%, $8.237 \%$, and $2.776 \%$ at the signal of $270 \mathrm{~nm}$ and $1.036 \%, 4.403 \%, 3.018 \%, 45.018 \%, 10.095 \%$, and $3.688 \%$ at the signal of $340 \mathrm{~nm}$, respectively.

3.5. Effect on Serum Insulin and C-Peptide Levels. As shown in Table 2, the serum insulin and C-peptide levels of NA/STZ-induced diabetic animals significantly decreased $(p<0.01 ;$ LSD); the recorded percentage changes were $-51.81 \%$ and $-66.77 \%$, respectively, as compared to the normal control. The administration of $C$. reticulata fruit peel extract, hesperidin, and quercetin to NA/STZ-induced diabetic rats produced a significant improvement $(p<0.01$; LSD) of the lowered levels. Hesperidin was the most effective in improving the lowered levels in diabetic rats; the recorded percentage changes were $88.17 \%$ and $132.32 \%$, respectively, in comparison with the diabetic control rats. With regard to one-way ANOVA, the general effect on levels of serum insulin and C-peptide between groups was very highly significant $(p<0.001 ; F$-probability) throughout the experiment.

3.6. Effect on Homeostasis Model Assessment of Insulin Resistance (IR), Insulin Sensitivity (IS), and $\beta$-Cell Function. As represented in Table 3, HOMA-IS and HOMA- $\beta$ cell function of NA/STZ-induced diabetic rats exhibited a highly significant depletion $(p<0.01)$, while the HOMA-IR index exhibited a significant elevation $(p<0.01$; LSD) in comparison with normal rats; the recorded percentage changes were $-54.05 \%,-73.60 \%$, and $98.88 \%$ for HOMA-IS, HOMA- $\beta$ cell function, and HOMA-IR, respectively. The administration of C. reticulata fruit peel extract, hesperidin, and quercetin to NA/STZ-induced diabetic rats produced a highly significant improvement of HOMA-IR, HOMA-IS, and HOMA- $\beta$ cell function $(p<0.01$; LSD) in comparison with the corresponding values of NA/STZ-induced diabetic control. With regard to one-way ANOVA, the general effect between groups was very highly significant since the $F$-probability has $p<0.001$.

3.7. Effects on Liver Glycogen Content and G-6-Pase and Glycogen Phosphorylase Activities. Liver glycogen content exhibited a significant depletion $(p<0.01$; LSD) in NA/STZinduced diabetic rats in comparison with the normal group; the recorded percentage decrease was $63.12 \%$. The 


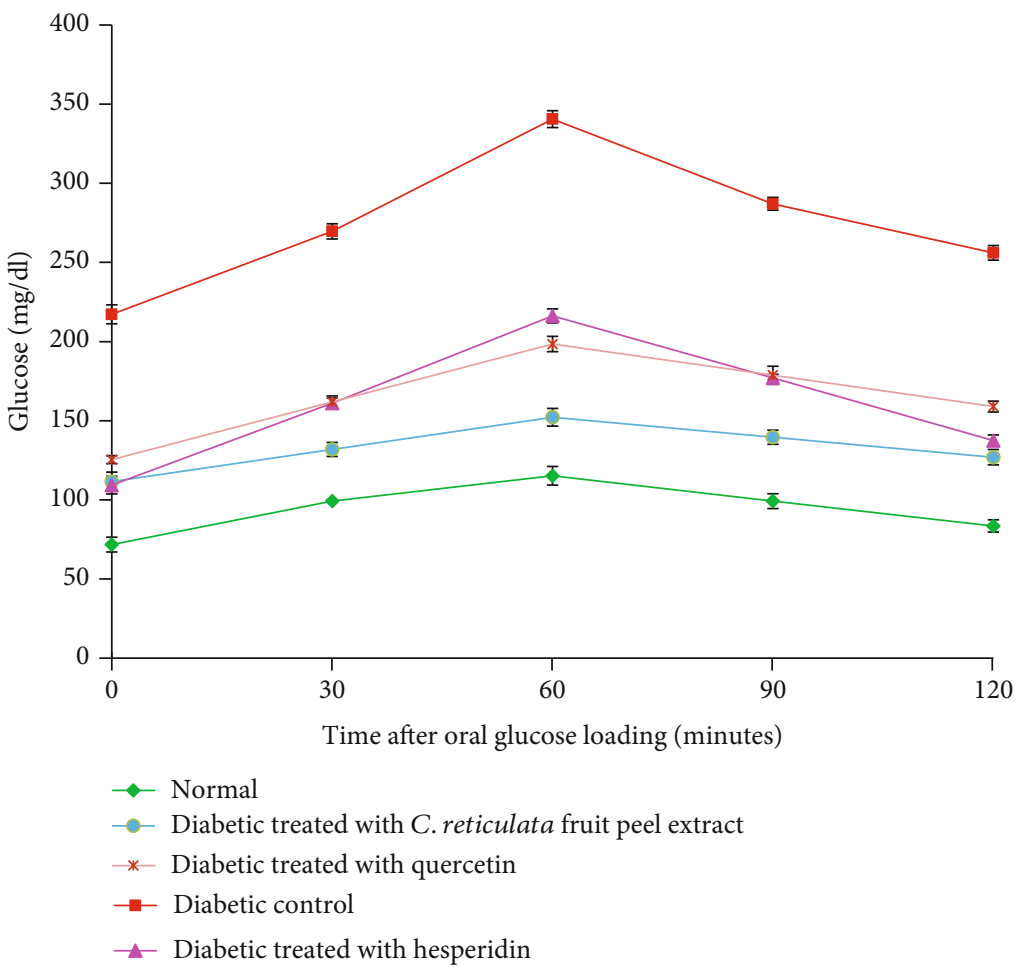

FIGURE 3: OGT in normal, diabetic control, and diabetic groups treated with C. reticulata fruit peel extract, hesperidin, and quercetin. $F$ -probability: $p<0.001$; LSD at the 5\% level: 64.80 ; LSD at the $1 \%$ level: 88.30 .

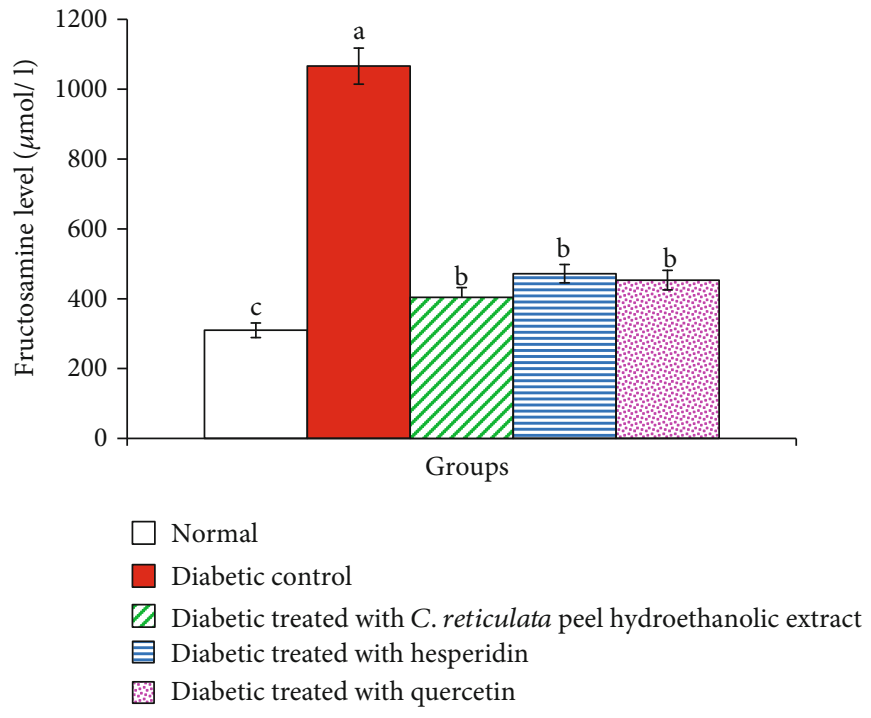

FIgURE 4: Serum fructosamine level in in normal, diabetic control, and diabetic groups treated with C. reticulata fruit peel extract, hesperidin, and quercetin. Means which have different letters are significantly different at $p<0.05$.

administration of C. reticulata fruit peel extract, hesperidin, and quercetin to NA/STZ-induced diabetic rats caused a significant improvement $(p<0.01$; LSD) in liver glycogen content. Hesperidin seemed to be the most effective in increasing the liver glycogen content of diabetic rats; the recorded percentage increase was $94.70 \%$ in comparison with the diabetic control (Table 4).

Liver G-6-Pase and glycogen phosphorylase activities in the liver of diabetic Wistar rats, on the other hand, exhibited a significant increase $(p<0.01$;SD) in comparison with the normal group; the recorded percentage changes were, respectively, $217.20 \%$ and $11.02 \%$. The administration of C. reticulata fruit peel extract, hesperidin, and quercetin to NA/STZinduced diabetic rats induced a significant amelioration $(p<0.01 ;$ LSD) of the raised enzyme activities. With regard to one-way ANOVA, the general effect between groups was very highly significant since the $F$-probability has $p<0.001$ (Table 4). 
TABle 2: Serum insulin and C-peptide levels in normal, diabetic control, and diabetic groups treated with C. reticulata fruit peel extract, hesperidin, and quercetin.

\begin{tabular}{|c|c|c|c|c|}
\hline Parameter groups & Insulin $(\mathrm{ng} / \mathrm{ml})$ & $\%$ change & C-peptide (ng/ml) & $\%$ change \\
\hline Normal & $1.93 \pm 0.073^{\mathrm{a}}$ & - & $2.98 \pm 0.05^{\mathrm{a}}$ & - \\
\hline Diabetic control & $0.93 \pm 0.04^{\mathrm{c}}$ & -51.81 & $0.99 \pm 0.04^{\mathrm{c}}$ & -66.77 \\
\hline Diabetic treated with fruit peel extract & $1.44 \pm 0.10^{\mathrm{b}}$ & 54.83 & $1.56 \pm 0.10^{\mathrm{b}}$ & 57.57 \\
\hline Diabetic treated with hesperidin & $1.75 \pm 0.05^{\mathrm{b}}$ & 88.17 & $2.30 \pm 0.13^{\mathrm{b}}$ & 132.32 \\
\hline Diabetic treated with quercetin & $1.53 \pm 0.11^{\mathrm{b}}$ & 62.51 & $2.29 \pm 0.15^{\mathrm{b}}$ & 131.31 \\
\hline$F$-probability & \multicolumn{2}{|c|}{$p<0.001$} & \multicolumn{2}{|c|}{$p<0.001$} \\
\hline LSD at $5 \%$ level & \multicolumn{2}{|c|}{0.308} & \multicolumn{2}{|c|}{0.362} \\
\hline LSD at $1 \%$ level & \multicolumn{2}{|c|}{0.417} & \multicolumn{2}{|c|}{0.490} \\
\hline
\end{tabular}

Data are represented as mean \pm SEM of six rats. Means which share different superscript letters are significantly different at $p<0.05$. Percentage changes were calculated by comparing diabetic control with normal and diabetic treated groups with diabetic control.

TABle 3: HOMA-IR, HOMA-IS, and HOMA- $\beta$-cell function in normal, diabetic control, and diabetic groups treated with $C$. reticulata fruit peel extract, hesperidin, and quercetin.

\begin{tabular}{|c|c|c|c|c|c|c|}
\hline Parameter group & HOMA-IR & $\%$ change & HOMA-IS & $\%$ change & HOMA- $\beta$-cell function & $\%$ change \\
\hline Normal & $2.69 \pm 0.16^{\mathrm{c}}$ & - & $0.74 \pm 0.02^{\mathrm{a}}$ & - & $5.91 \pm 0.37^{\mathrm{a}}$ & - \\
\hline Diabetic control & $5.35 \pm 0.28^{\mathrm{a}}$ & 98.88 & $0.34 \pm 0.03^{\mathrm{c}}$ & -54.05 & $1.56 \pm 0.17^{\mathrm{c}}$ & -73.60 \\
\hline Diabetic treated with fruit peel extract & $3.31 \pm 0.34^{\mathrm{b}}$ & -38.13 & $0.70 \pm 0.03^{\mathrm{b}}$ & 105.88 & $3.22 \pm 0.25^{\mathrm{b}}$ & 106.41 \\
\hline Diabetic treated with hesperidin & $3.58 \pm 0.28^{\mathrm{b}}$ & -33.08 & $0.62 \pm 0.05^{\mathrm{b}}$ & 82.35 & $3.91 \pm 0.28^{\mathrm{b}}$ & 150.64 \\
\hline Diabetic treated with quercetin & $3.19 \pm 0.23^{\mathrm{b}}$ & -40.37 & $0.64 \pm 0.02^{\mathrm{b}}$ & 88.23 & $3.08 \pm 0.22^{\mathrm{b}}$ & 97.43 \\
\hline$F$-probability & $p<0.001$ & & $p<0.001$ & & $p<0.001$ & \\
\hline LSD at $5 \%$ level & \multicolumn{2}{|c|}{0.73} & \multicolumn{2}{|c|}{0.10} & \multicolumn{2}{|l|}{0.84} \\
\hline LSD at $1 \%$ level & \multicolumn{2}{|c|}{0.98} & \multicolumn{2}{|c|}{0.12} & \multicolumn{2}{|l|}{1.14} \\
\hline
\end{tabular}

Data are represented as mean \pm SEM of six rats. Means which have different superscript letters are significantly different at $p<0.05$. Percentage changes were calculated by comparing diabetic control with normal and diabetic treated groups with diabetic control.

TABLE 4: Liver glycogen content, G-6-Pase, and glycogen phosphorylase activities in normal, diabetic control, and diabetic groups treated with C. reticulata fruit peel extract, hesperidin, and quercetin.

\begin{tabular}{|c|c|c|c|c|c|c|}
\hline Parameter groups & $\begin{array}{c}\text { Glycogen } \\
\text { (mg/g tissue) }\end{array}$ & $\%$ change & $\begin{array}{c}\text { G-6-Pase } \\
\text { (mg Pi liberated/g } \\
\text { tissue/hour) }\end{array}$ & $\%$ change & $\begin{array}{c}\text { Glycogen } \\
\text { phosphorylase activity } \\
\text { (mg Pi liberated/g } \\
\text { tissue/hr) }\end{array}$ & $\%$ change \\
\hline Normal & $22.02 \pm 2.34^{\mathrm{a}}$ & - & $18.89 \pm 1.61^{\mathrm{c}}$ & - & $12.35 \pm 0.43^{\mathrm{c}}$ & - \\
\hline Diabetic control & $8.12 \pm 0.80^{c}$ & -63.12 & $59.92 \pm 2.72^{\mathrm{a}}$ & 217.20 & $25.97 \pm 0.78^{\mathrm{a}}$ & 11.02 \\
\hline Diabetic treated with fruit peel extract & $14.03 \pm 0.72^{\mathrm{b}}$ & 72.78 & $35.30 \pm 1.81^{\mathrm{b}}$ & -41.08 & $15.65 \pm 0.047^{\mathrm{b}}$ & -39.73 \\
\hline Diabetic treated with hesperidin & $15.81 \pm 0.85^{\mathrm{b}}$ & 94.70 & $36.10 \pm 1.82^{\mathrm{b}}$ & -39.75 & $16.03 \pm 0.67^{\mathrm{b}}$ & -38.27 \\
\hline Diabetic treated with quercetin & $13.07 \pm 0.50^{\mathrm{b}}$ & 60.96 & $33.51 \pm 2.31^{\mathrm{b}}$ & -44.07 & $15.70 \pm 0.35^{\mathrm{b}}$ & -39.54 \\
\hline$F$-probability & $p<0.001$ & & $p<0.001$ & & $p<0.001$ & \\
\hline LSD at $5 \%$ level & 3.60 & & 6.11 & & 1.65 & \\
\hline LSD at $1 \%$ level & 4.87 & & 8.27 & & 2.24 & \\
\hline
\end{tabular}

Data are represented as mean \pm SEM of six rats. Means which have different superscript letters are significantly different at $p<0.05$. Percentage changes were calculated by comparing diabetic control with normal and diabetic treated groups with diabetic control.

3.8. Effect on Serum Lipid Profile and FFA Level. The TC, TG, LDL-C, vLDL, and FFA levels (Table 5) showed a significant $(p<0.01 ; \mathrm{LSD})$ elevation in serum of NA/STZ-induced diabetic rats as compared with the normal group, but the serum HDL-C level exhibited a significant decrease $(p<0.01$; LSD). The treatment of diabetic rats with fruit peel extract, hesperidin, and quercetin caused a significant improvement $(p<0.01$; LSD) in TC, TG, HDL-C, LDL-cholesterol, vLDL level, and FFA levels. While hesperidin was the most effective in improving TG, vLDL-C, and FFA levels in diabetic animals, the fruit peel extract was the most effective in amending the deteriorated TC and HDL-C and LDL-C 
TABLE 5: Serum lipid profile and FFA levels in normal, diabetic control, and diabetic groups treated with C. reticulata fruit peel extract, hesperidin, and quercetin.

\begin{tabular}{lcccccc}
\hline Parameter groups & TC $(\mathrm{mg} / \mathrm{dl})$ & TG $(\mathrm{mg} / \mathrm{dl})$ & HDL-C $(\mathrm{mg} / \mathrm{dl})$ & LDL-C $(\mathrm{mg} / \mathrm{dl})$ & vLDL-C $(\mathrm{mg} / \mathrm{dl})$ & FFAs $(\mathrm{mg} / \mathrm{dl})$ \\
\hline Normal & $55.8 \pm 2.23^{\mathrm{c}}$ & $58 \pm 3.10^{\mathrm{c}}$ & $28.3 \pm 0.73^{\mathrm{a}}$ & $16.04 \pm 1.87^{\mathrm{c}}$ & $11.35 \pm 0.63^{\mathrm{c}}$ & $14.71 \pm 0.33^{\mathrm{c}}$ \\
Diabetic control & $92.43 \pm 4.50^{\mathrm{a}}$ & $99.36 \pm 2.43^{\mathrm{a}}$ & $18.94 \pm 0.55^{\mathrm{c}}$ & $52.70 \pm 4.38^{\mathrm{a}}$ & $19.95 \pm 0.48^{\mathrm{a}}$ & $36.43 \pm 1.62^{\mathrm{a}}$ \\
Diabetic treated with fruit peel extract & $65.65 \pm 2.83^{\mathrm{b}}$ & $77.48 \pm 3.05$ & $23.10 \pm 0.56^{\mathrm{b}}$ & $27.19 \pm 3.16^{\mathrm{b}}$ & $15.36 \pm 0.53^{\mathrm{b}}$ & $26.39 \pm 0.93^{\mathrm{b}}$ \\
Diabetic treated with hesperidin & $70.72 \pm 2.79^{\mathrm{b}}$ & $74.53 \pm 3.59^{\mathrm{b}}$ & $22.37 \pm 0.44^{\mathrm{b}}$ & $34.07 \pm 2.40^{\mathrm{b}}$ & $15.12 \pm 0.69^{\mathrm{b}}$ & $23.27 \pm 0.62^{\mathrm{b}}$ \\
Diabetic treated with quercetin & $73.37 \pm 3.09^{\mathrm{b}}$ & $78.96 \pm 3.46^{\mathrm{b}}$ & $22.88 \pm 0.62$ & $36.93 \pm 3.72^{\mathrm{b}}$ & $15.46 \pm 0.53^{\mathrm{b}}$ & $24.83 \pm 1.15^{\mathrm{b}}$ \\
F-probability & $p<0.001$ & $p<0.001$ & $p<0.001$ & $p<0.001$ & $p<0.001$ & $p<0.001$ \\
LSD at the 5\% level & 9.27 & 9.19 & 1.72 & 9.43 & 1.70 & 3.01 \\
LSD at the 1\% level & 12.55 & 12.44 & 2.33 & 12.77 & 2.30 & 4.07 \\
\hline
\end{tabular}

Data are represented as mean \pm SEM of six rats. Means which have different superscript letters are significantly different at $p<0.05$. Percentage changes were calculated by comparing diabetic control with normal and diabetic treated groups with diabetic control.

TABle 6: Serum AST and ALT activities in normal, diabetic control, and diabetic groups treated with C. reticulata fruit peel extract, hesperidin, and quercetin.

\begin{tabular}{|c|c|c|c|c|}
\hline Parameter groups & AST (U/l) & $\%$ change & $\operatorname{ALT}(\mathrm{U} / \mathrm{l})$ & $\%$ change \\
\hline Normal & $127.83 \pm 2.22^{\mathrm{c}}$ & - & $25.15 \pm 1.14^{\mathrm{c}}$ & - \\
\hline Diabetic control & $193.33 \pm 2.98^{\mathrm{a}}$ & $51.23 \%$ & $46.36 \pm 1.45^{\mathrm{a}}$ & $84.33 \%$ \\
\hline Diabetic treated with fruit peel extract & $148 \pm 1.90^{\mathrm{b}}$ & $-23.44 \%$ & $31.00 \pm 1.36^{\mathrm{b}}$ & $-33.13 \%$ \\
\hline Diabetic treated with hesperidin & $131.5 \pm 2.20^{\mathrm{b}}$ & $-31.98 \%$ & $33.06 \pm 1.66^{\mathrm{b}}$ & $-28.68 \%$ \\
\hline Diabetic treated with quercetin & $141.9 \pm 3.16^{\mathrm{b}}$ & $-26.60 \%$ & $31.63 \pm 1.42^{\mathrm{b}}$ & $-31.77 \%$ \\
\hline$F$-probability & \multicolumn{2}{|c|}{$p<0.001$} & \multicolumn{2}{|c|}{$p<0.001$} \\
\hline LSD at $5 \%$ level & \multicolumn{2}{|c|}{8.98} & \multicolumn{2}{|c|}{5.15} \\
\hline LSD at $1 \%$ level & \multicolumn{2}{|c|}{12.15} & \multicolumn{2}{|c|}{6.97} \\
\hline
\end{tabular}

Data are represented as mean \pm SEM of six rats. Means which have different superscript letters are significantly different at $p<0.05$. Percentage changes were calculated by comparing diabetic control with normal and diabetic treated groups with diabetic control.

levels (Table 5). With regard to one-way ANOVA, the effect between groups on serum TC, TG, LDL-C, vLDL, and FFA levels was very highly significant since the $F$-probability has $p<0.001$.

3.9. Effect on Serum AST and ALT Activities. The activities of serum AST and ALT in NA/STZ-induced diabetic rats showed a significant elevation $(p<0.01$; LSD); the recorded percentage changes were $51.23 \%$ and $84.33 \%$, respectively. The administration of $C$. reticulata fruit peel extract, hesperidin, and quercetin to NA/STZ-induced diabetic rats resulted in a significant $(p<0.001$; LSD) improvement of AST and ALT activities. The treatment with hesperidin was the most potent in improving the elevated AST activity. With regard to one-way ANOVA, the general effect on serum AST and ALT activities between groups was very highly significant $(p<0.001 ; F$-probability) (Table 6).

3.10. Effect of Serum Parameters Related to Kidney Functions. Serum creatinine and urea of NA/STZ-induced diabetic rats exhibited a significant increase $(p<0.01$; LSD) in comparison with the normal control; the recorded percentage increases were $116.11 \%$ and $64.78 \%$, respectively. All treatments including C. reticulata peel fruit peel extract, hesperidin, and quercetin caused a significant decrease in serum creatinine and urea $(p<0.01$; LSD) in comparison with diabetic control. The treatment with hesperidin was the most effective in improving the elevated serum creatinine and urea recording percentage decreases of $41.06 \%$ and $34.80 \%$, respectively. One-way ANOVA indicated that the effect on serum creatinine and urea between groups was very highly significant $(p<0.001 ; F$-probability) (Table 7$)$.

\subsection{Effect on Liver Oxidative Stress and Antioxidant Defense} Parameters. The diabetic rats exhibited a significant increase $(p<0.01$; LSD) in LPO; the recorded percentage change was $126.10 \%$ in comparison with the normal group. The treatment of diabetic rats with $C$. reticulata fruit peel hydroethanolic extract, hesperidin, and quercetin produced a significant improvement of the elevated LPO. The three treatments have no significant effects when compared with each other; thus, their effects were more or less similar as compared with the diabetic control (Table 8).

Liver GSH, GPx, GST, and SOD levels significantly decreased $(p<0.01$;SD) in the diabetic control group. The treatment of diabetic rats with $C$. reticulata fruit peel extract, hesperidin, and quercetin induced a significant improvement of lowered GSH content, GPx, GST, and SOD activities. The treatment of $C$. reticulata fruit peel hydroethanolic extract 
TABLE 7: Serum creatinine and urea level in normal, diabetic control, and diabetic groups treated with C. reticulata fruit peel extract, hesperidin, and quercetin.

\begin{tabular}{|c|c|c|c|c|}
\hline Parameter groups & Creatinine $(\mathrm{mg} / \mathrm{dl})$ & $\%$ change & Urea $(\mathrm{mg} / \mathrm{dl})$ & $\%$ change \\
\hline Normal & $3.91 \pm 0.49^{\mathrm{d}}$ & - & $21.41 \pm 1.9^{\mathrm{d}}$ & - \\
\hline Diabetic control & $8.45 \pm 0.92^{\mathrm{a}}$ & 116.11 & $35.28 \pm 2.00^{\mathrm{a}}$ & 64.78 \\
\hline Diabetic treated with fruit peel extract & $6.03 \pm 0.59^{b}$ & -28.63 & $27 \pm 2.01^{\mathrm{b}}$ & -23.46 \\
\hline Diabetic treated with hesperidin & $4.98 \pm 0.50^{\mathrm{c}}$ & -41.06 & $23 \pm 1.80^{\mathrm{cd}}$ & -34.80 \\
\hline Diabetic treated with quercetin & $5.40 \pm 0.60^{\mathrm{bc}}$ & -36.09 & $25.31 \pm 1.60^{\mathrm{bc}}$ & -28.25 \\
\hline$F$-probability & \multicolumn{2}{|c|}{$p<0.001$} & \multicolumn{2}{|c|}{$p<0.001$} \\
\hline LSD at $5 \%$ level & \multicolumn{2}{|c|}{0.08} & \multicolumn{2}{|c|}{3.69} \\
\hline LSD at $1 \%$ level & \multicolumn{2}{|c|}{0.10} & \multicolumn{2}{|c|}{5.01} \\
\hline
\end{tabular}

Data are represented as mean \pm SEM of six rats. Means which have different superscript letters are significantly different at $p<0.05$. Percentage changes were calculated by comparing diabetic control with normal and diabetic treated groups with diabetic control.

TABLE 8: Liver oxidative stress and antioxidant defense markers in normal, diabetic control, and diabetic groups treated with C. reticulata fruit peel extract, hesperidin, and quercetin.

\begin{tabular}{|c|c|c|c|c|c|}
\hline Parameter groups & $\begin{array}{c}\text { LPO } \\
\text { (nmole/MDA/100 mg } \\
\text { tissue) }\end{array}$ & $\begin{array}{c}\mathrm{GSH} \\
\text { (nmole/100 mg } \\
\text { tissue) }\end{array}$ & $\begin{array}{c}\mathrm{GPx} \\
(\mathrm{mU} / 100 \mathrm{mg} \\
\text { tissue) }\end{array}$ & $\begin{array}{c}\text { GST } \\
\text { (U/100 mg } \\
\text { tissue) }\end{array}$ & $\begin{array}{l}\text { SOD } \\
\text { (U/mg } \\
\text { tissue) }\end{array}$ \\
\hline Normal & $25.13 \pm 0.68^{c}$ & $50.03 \pm 2.6^{\mathrm{a}}$ & $183.06 \pm 1.7^{\mathrm{a}}$ & $160.43 \pm 1.73^{\mathrm{a}}$ & $31.80 \pm 1.97^{\mathrm{a}}$ \\
\hline Diabetic control & $56.82 \pm 1.05^{\mathrm{a}}$ & $21.13 \pm 1.2^{\mathrm{c}}$ & $113.97 \pm 2.5^{\mathrm{d}}$ & $83.11 \pm 3.28^{\mathrm{c}}$ & $17.43 \pm 0.92^{\mathrm{c}}$ \\
\hline $\begin{array}{l}\text { Diabetic treated with fruit } \\
\text { peel extract }\end{array}$ & $39.09 \pm 1.67^{\mathrm{b}}$ & $32.33 \pm 0.91^{\mathrm{b}}$ & $153.66 \pm 2.9^{b}$ & $116.94 \pm 4.97^{\mathrm{b}}$ & $24.98 \pm 1.03^{\mathrm{b}}$ \\
\hline Diabetic treated with hesperidin & $36.39 \pm 2.07^{\mathrm{b}}$ & $32.70 \pm 1.8^{\mathrm{b}}$ & $136.54 \pm 3.25^{\mathrm{c}}$ & $112.77 \pm 2.85^{\mathrm{b}}$ & $23.75 \pm 1.44^{\mathrm{b}}$ \\
\hline Diabetic treated with quercetin & $36.31 \pm 2.16^{\mathrm{b}}$ & $33.14 \pm 1.9^{\mathrm{b}}$ & $138.26 \pm 2.60^{\mathrm{c}}$ & $125.14 \pm 4.18^{\mathrm{b}}$ & $26.79 \pm 1.57^{\mathrm{b}}$ \\
\hline$F$-probability & $p<0.001$ & $p<0.001$ & $p<0.001$ & $p<0.001$ & $p<0.001$ \\
\hline LSD at $5 \%$ level & 4.765 & 5.35 & 9.31 & 10.44 & 4.39 \\
\hline LSD at $1 \%$ level & 6.447 & 7.24 & 12.59 & 14.12 & 5.95 \\
\hline
\end{tabular}

Data are represented as mean \pm SEM of six rats. Means which have different superscript letters are significantly different at $p<0.05$. Percentage changes were calculated by comparing diabetic control with normal and diabetic treated groups with diabetic control.

was the most effective in increasing GPx activity, while the GSH content and GST and SOD activities were not significant when the three treatments were compared with each other. Regarding one-way ANOVA, the effect between groups was very highly significant since the $F$-probability has $p<0.001$ (Table 8).

3.12. Histological Effects. The pancreas histological changes in NA/STZ-induced diabetic rats and effects of treatments of diabetic rats with $C$. reticulata fruit peel extract, hesperidin, and quercetin are depicted in Figures 5(a)-5(e). The pancreas of normal rats has intact organized pancreatic acini and islets of Langerhans that contain $\alpha$-, $\beta$-, and $\delta$-cells (Figure 5(a)). The diabetic rats showed a decrease in the size of the pancreatic islets, which have a decreased number of islet cells, necrosis, and vacuolations (Figure 5(b)). The treatments of diabetic rats with $C$. reticulata fruit peel extract, hesperidin, and quercetin induced a remarkable improvement in the islets' histological architecture and integrity as observed in Figures 5(c)-5(e), respectively. The treatment with hesperidin seemed to be the most potent in amending the islet histological architecture of diabetic rats. Although the pancreatic islets of diabetic rats treated with quercetin have the largest size, they still exhibited vacuolations and degenerative changes.

3.13. Effects on Adipose Tissue mRNA Expressions of Various Genes. C. reticulata fruit peel extract, hesperidin, and quercetin effects on adipose tissue GLUT- 4 , insulin receptor $\beta$-subunit, and adiponectin mRNA expressions relative to $\beta$-actin in visceral adipose tissue of diabetic rats are depicted in Figures 6, 7, and 8, respectively. The mRNA expressions of GLUT-4, insulin receptor $\beta$-subunit, and adiponectin mRNA expressions were significantly depleted in diabetic rats. The oral administration of $C$. reticulata fruit peel extract, hesperidin, and quercetin to diabetic rats significantly increased the suppressed mRNA expressions of GLUT-4 and insulin receptor $\beta$-subunit mRNA gene expressions. The treatment with hesperidin seemed to be the most potent in increasing adipose tissue insulin receptor $\beta$-subunit mRNA expression. Moreover, the effect of $C$. reticulata fruit peel extract and hesperidin produced a nonsignificant increase $(p>0.05$; LSD) in visceral adipose tissue adiponectin mRNA expression relative to $\beta$-actin, while the treatment with quercetin induced a significant increase of adiponectin mRNA expression. Concerning one-way ANOVA, the effect between groups 


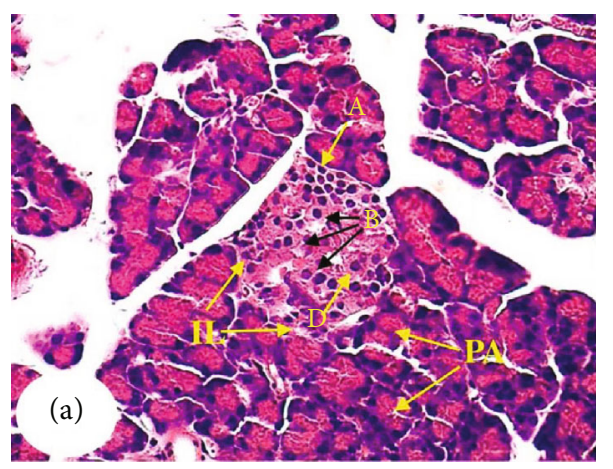

(a)

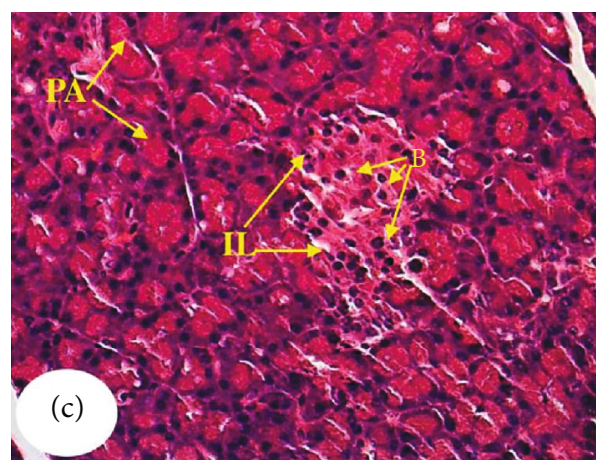

(c)

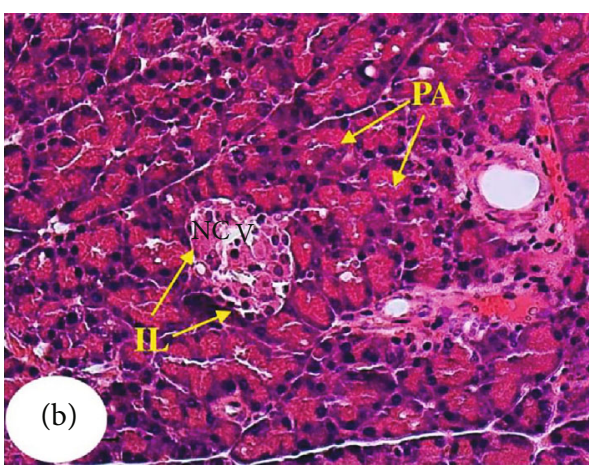

(b)

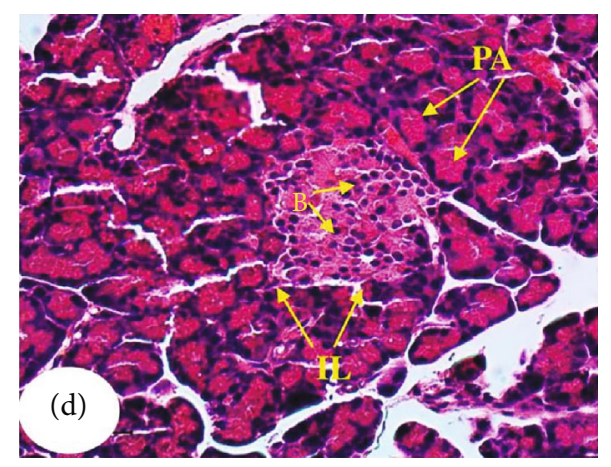

(d)

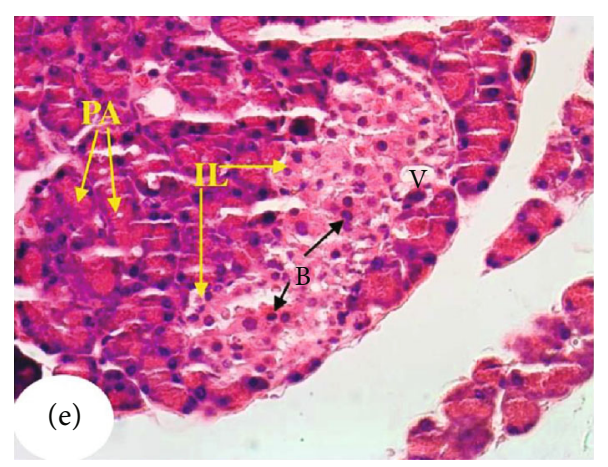

(e)

FIgURE 5: Photomicrographs of pancreata of normal (a), diabetic control (b), and diabetic rats treated with C. reticulata fruit peel extract (c), hesperidin (d), and quercetin (e). PA: pancreatic acini; IL: islet of Langerhans; A: alpha cells; B: beta cells; D: delta cells; V: vacuolation; and NC: necrosis.

on visceral adipose tissue mRNA expressions of the detected genes was very highly significant since the $F$-probability has $p<0.001$.

\section{Discussion}

T2DM is characterized by insulin resistance which may be due to insulin receptor and/or postreceptor defects. This defect leads to an impairment in the regulation of carbohydrate, lipid, and protein metabolism. Moreover, patients with T2DM have an increased hepatic glucose production and insulin insensitivity in skeletal muscle and adipose tissue or a combination of both and long-term persistent inflammation, all of which progressively disrupt control of glucose concentrations in blood and result in an occurrence of deleterious diabetic complications [72-74]. The persistent long-term hyperglycemia of DM is accompanied by chronic damage and dysfunction of different organs [75]. The NA/STZ-induced DM model has been proposed as experimental DM in rat since it exhibits features like human diabetes and is suitable for acute and chronic studies; thus, it is considered as a good model for the study of hyperglycemia [76-80].

STZ is often used to induce experimental DM in animals. The cytotoxic action of STZ is mediated by the excessive production of reactive oxygen species (ROS) causing oxidative damage that causes damage to $\beta$-cells via the activation of apoptosis and attenuation of insulin 


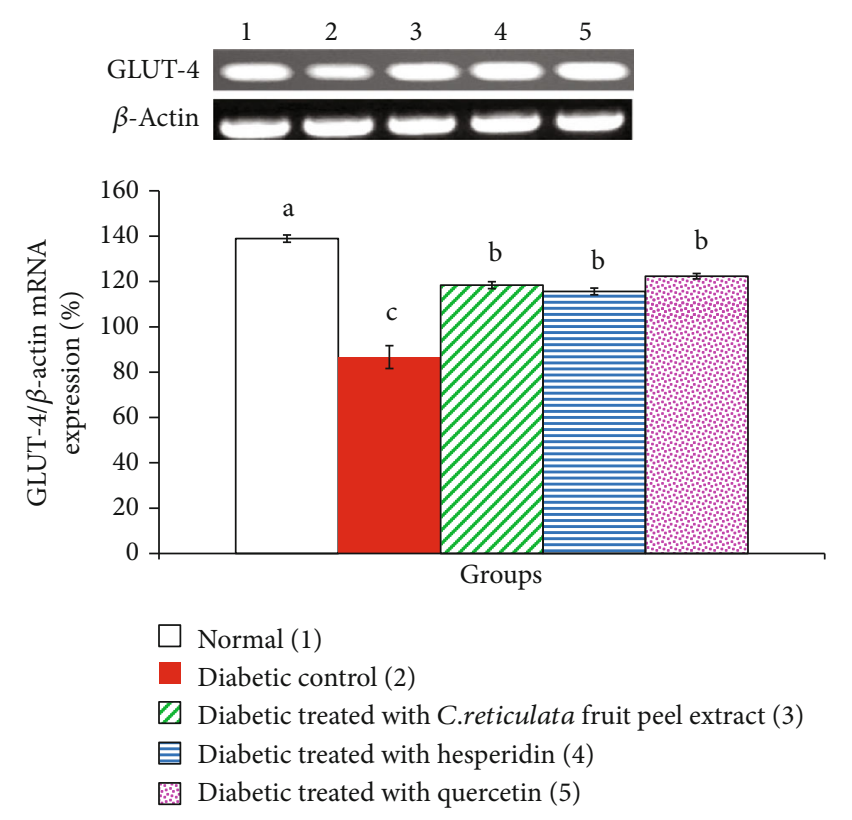

Figure 6: Visceral adipose tissue GLUT-4 mRNA expression relative to $\beta$-actin in normal, diabetic control, and diabetic groups treated with $C$. reticulata fruit peel extract, hesperidin, and quercetin. Means which have different letters are significantly different at $p<0.05$.
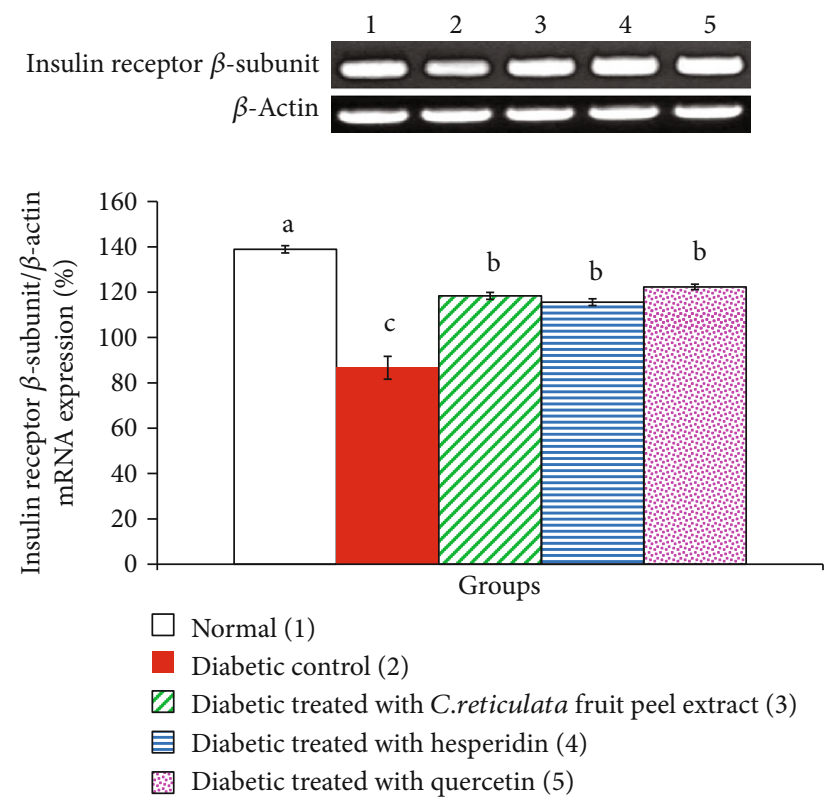

FIgURE 7: Visceral adipose tissue insulin receptor $\beta$-subunit mRNA expression relative to $\beta$-actin in normal, diabetic control, and diabetic groups treated with $C$. reticulata fruit peel extract, hesperidin, and quercetin. Means which have different letters are significantly different at $p<0.05$.

synthesis $[11,13,81-83]$. STZ enters the $\beta$-cell via GLUT2 , because it is similar enough to glucose so that it can be transported into the cell; however, it is not recognized by the other glucose transporter types (GLUTs). The $\beta$-cells

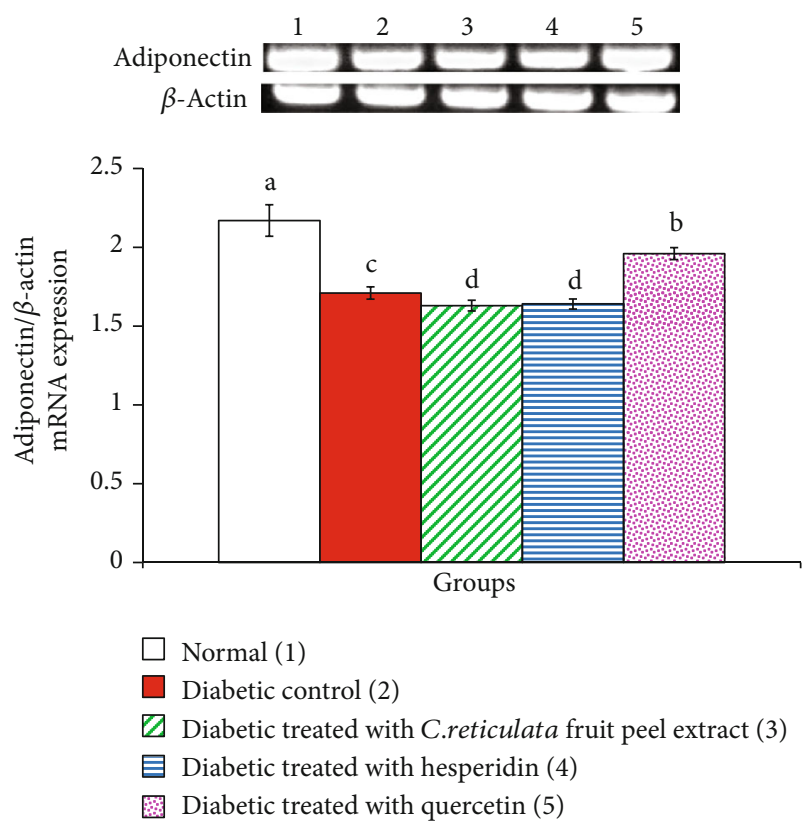

Figure 8: Visceral adipose tissue adiponectin mRNA expression relative to $\beta$-actin in normal, diabetic control, and diabetic groups treated with $C$. reticulata fruit peel extract, hesperidin, and quercetin. Means which have different letters are significantly different at $p<0.05$.

possess high levels of GLUT-2; this explains the relative toxicity of STZ to $\beta$-cells [18]. The NA/STZ-induced T2DM rat model has been used in the present study because of the following lineaments: (a) stable moderate nonfasting hyperglycemia which requires no exogenous insulin to survive; (b) partial loss of $\beta$-cells in the islets of Langerhans (-40\%); (c) decrease in islets' insulin content by $60 \%$; (d) impaired glucose tolerance; (e) impaired glucosestimulated insulin secretion; (f) responsiveness to sulfonylurea drugs; and (g) polyphagia and polydipsia [18].

Plants, used in traditional medicine to treat DM, represent valuable alternatives for the control of this disease [84]. The phytomedicines and functional foods play positive roles in the control and management of blood glucose concentrations, glucose uptake into peripheral tissues, insulin secretion, and immune function to prevent DM $[85,86]$. Antioxidants from natural sources help in scavenging and removing ROS and significantly reducing the probabilities of progression of DM and its complications. Varieties of nutritionally important vitamins, some supplements, and ingredients from natural food sources may prevent the injury and deterioration caused by oxidative stress in DM. Hence, the plant kingdom has become an important target for the search of novel drugs and biologically active compounds $[87,88]$.

Tangerine (C. reticulata) fruit peel hydroethanolic extract contains rich phytochemicals as indicated in the present study by GC-MS and HPLC-MS analyses. Many of these phytochemicals have potent biological activities. $4 \mathrm{H}$-pyran4-one, detected by GC-MS at retention times of 16.556 and 27.356 minutes, is a cyclic nucleus in the chemical structures 
of many flavonoids including quercetin, naringin, hesperidin, nobiletin, and tangeretin. Polymethoxyflavones are represented in a GC-MS chromatogram at a retention time of 27.047 minutes. Moreover, the $\beta$-D-glucopyranose, $4-\mathrm{O}-\beta$ $D$-galactopyranosyl- peak observed at a retention time of 27.365 is a glycoside moiety of a number of flavonoids such as quercetin 3 -O- $\beta$-D-glucopyranosyl $(1 \rightarrow 2)-\beta$-D-galactopyranoside-7-O- $\beta$-D-glucuropyranoside (1) and kaempferol 3-O- $\beta$-D-glucopyranosyl $(1 \rightarrow 2)-\beta$-D-galacto-pyranoside-7$O-\beta$-D-glucuropyranoside [89]. On the other hand, HPLCMS analysis indicated the presence of gallic acid, naringin, quercetin, hesperidin, nobiletin, and tangeretin. Hesperidin, naringin, and nobiletin were the most abundant. In the current study, hesperidin (which is a major component of the $C$. reticulata fruit peel hydroethanolic extract) and quercetin (which is one of its minor components) were purchased from Sigma-Aldrich Chemical Company (USA) and were tested for antidiabetic and antioxidant effects in comparison with the crude extract.

OGTT is a well accepted test to screen the antihyperglycemic efficacy of any hypoglycemic agents $[1,90,91]$. In the present study, NA/STZ-induced diabetic rats showed an elevation in serum glucose levels at all points of OGTT as compared with normal rats; these data are in concordance with other previous studies [92-95]. Concomitantly, the serum fructosamine level, which represents an accurate measure of mean blood glucose concentration over several days or weeks (2-3 weeks), was also significantly increased in NA/STZinduced diabetic rats. Either a decrease in insulin secretion as in the case of insulin IDDM or a defect in tissue insulin sensitivity as in NIDDM could be the cause of a rise in serum glucose and fructosamine levels [96-98]. The elevation in blood glucose levels and the inhibition of the insulin synthesis may be referred to (1) a reduced uptake of glucose into peripheral tissues, muscles, and adipose tissues and insulin resistance which may not only induce hyperglycemia but also dyslipidemia [95, 99]; (2) a loss of activity and breakdown of the liver glycogen synthetase-activating system [100]; and (3) a significant decrease in the activities of the glycolytic and lipogenic enzymes, while there was an increase in the activities of gluconeogenic enzymes and hepatic glucose production [101].

The present study demonstrated that the treatment of diabetic rats with $C$. reticulata peel hydroethanolic extract, hesperidin, and quercetin caused potential ameliorative effects on OGT and the serum fructosamine level, and this is in concordance with the results of Jung et al. [102], Chakravarthy et al. [103], Chakravarthy et al. [104], Sharma et al. [105], Pandit et al. [106], and Kapoor and Kakkar [107] who revealed an analogous improvement effect of various flavonoids in different animal models of DM. An important finding of the present study is that the effect of $C$. reticulata fruit peel hydroethanolic extract has the most potent effect in improving OGT and in decreasing the elevated serum fructosamine level. The antihyperglycemic effect of the fruit peel hydroethanolic extract is more potent than the effects of hesperidin and quercetin due to the synergistic effects of these two flavonoids and other constituting flavonoids, such as naringin, and polymethoxylated flavones, viz., nobiletin and tangeretin, as indicated by GC-MS and HPLC-MS analyses in the present study. These flavonoids have been reported to have antidiabetic effects by many investigators $[1,18,84,108]$.

Homeostatic model assessment (HOMA), estimated from fasting glucose and insulin levels, is a method used to calculate insulin resistance, insulin sensitivity, and $\beta$-cell function [109].

In the present study, HOMA-IR exhibited a significant increase in NA/STZ-induced diabetic rats while HOMA-IS and HOMA- $\beta$ cell function showed a significant decrease; these changes in HOMA reflect the presence of insulin resistance (insulin insensitivity) and impaired $\beta$-cell function in the NA/STZ-induced diabetic rat model used in the present investigation. The treatment of diabetic rats with $C$. reticulata fruit peel extract, hesperidin, and quercetin successfully decreased elevated HOMA-IR and increased the lowered values of HOMA-IS and HOMA- $\beta$ cell function. These ameliorations in the HOMA indices led us to suggest that all tested treatments produced antihyperglycemic and antidiabetic actions via improvements in both tissue insulin sensitivity and $\beta$-cell function. It is relative here to mention that the increase in serum levels of both insulin and C-peptide after treatment of diabetic rats with $C$. reticulata peel hydroethanolic extract, hesperidin, and quercetin, in the present study, supports the evidence that these treatments improved $\beta$-cell function and insulin secretory response. Moreover, in association with the improvements in serum insulin and Cpeptide levels, the pancreatic islets exhibited an amendment of histological architecture and integrity together with the increase in the number of $\beta$-cells as a result of treatments of diabetic rats with $C$. reticulata peel hydroethanolic extract, hesperidin, and quercetin. On the other hand, the increase in adipose tissue GLUT- 4 and insulin receptor- $\beta$ subunit by treatments of diabetic rats with $C$. reticulata peel hydroethanolic extract, hesperidin, and quercetin reflects the improved adipose tissue (peripheral tissue) insulin sensitivity. Also, adiponectin significantly increased only as a result of quercetin treatment in the present study. As adiponectin is considered by previous publications as an insulin sensitizer $[110,111]$, it may importantly contribute to reduce insulin resistance and promote insulin-sensitizing activity due to the treatment of diabetic rats with quercetin.

Liver glycogen content may be regarded as biomarker for evaluating antihyperglycemic efficiency of any drug especially in experimental animals [95]. The raised hepatic glucose production in DM could be a result from glycogenolysis or gluconeogenesis or both, as stated by Ahmed et al. [112] and Raju et al. [101]. The present study exhibited a depletion in the hepatic glycogen content in association with an intense increase of hepatic glycogen phosphorylase and G6-Pase activities when compared with normal rats. These results are in concordance with those of Ahmed et al. [112], Pari and Suman [84], Morral [113], and Ahmed [114], who demonstrated that NA/STZ-induced DM resulted in reduced hepatic glycogen content and elevated hepatic G-6-Pase and glycogen phosphorylase activities in diabetic rats. In the current study, the treatment of diabetic rats with $C$. reticulata fruit peel hydroethanolic extract, hesperidin, and quercetin 
induced a significant increase in liver glycogen content in association with a significant decrease in liver G-6-pase and glycogen phosphorylase activities; the three treatments have nearly similar effects. These improvements in the diabetic treated rats may reflect the decrease in hepatic glucose production which, in turn, leads to a decrease in the plasma glucose concentration. In addition to the previous mechanism, it was reported that the increased peripheral glucose uptake and reduced G-6-Pase activity may inhibit glycogen phosphorylase and also activate glycogen synthetase in the liver and muscles [115]. Furthermore, the present results also run parallel with Jung et al. [116] who revealed that hesperidin decreased the activities of gluconeogenic enzymes in T2DM. In addition to this, Eid and Haddad [117] stated that quercetin decreased G-6-Pase activity, which controls wholebody glucose homeostasis in NA/STZ-induced diabetic rats. In the same way, the current results are also in concordance with Mahmoud et al.'s study [1], which stated that flavonoids such as hesperidin and naringin caused a reduction in glycogen phosphorylase and G-6-Pase activities in NA/STZinduced T2DM in rats. Thus, based on our results and those of previous publications, it can be elucidated that the improvements in the liver glycogen content and the decrease in glycogen phosphorylase and G-6-Pase activities as a result of treatments play an important role in the control of hepatic glucose production, and in turn, the control of blood glucose level. In addition, these ameliorations may be secondary to the increase in blood insulin level and alleviations in tissue insulin sensitivity.

It is well known that DM is usually accompanied by alterations in lipid and lipoprotein profile [91]. In the current study, the elevation in serum glucose level was concomitant with a remarkable increase in serum TC, LDL-C, and TG levels and a decrease in serum HDL-C in NA/STZ diabetic rats. These observations run parallel with Kapoor and Kakkar [107], Ulicna et al. [118], Wasan et al. [119], Wittenstein et al. [120], and Singh and Singh [121] who reported high levels of LDL-C and vLDL-C in poorly controlled diabetic patients and diabetic rats. In the present study, the treatments with the $C$. reticulata fruit peel hydroethanolic extract, hesperidin, and quercetin enhanced a significant alleviation of the altered serum lipids. These evidences are in accordance with the results published by Gorinstein et al. [122], Zhou et al. [123], and Li et al. [91], which demonstrated that the treatments with various flavonoids increased serum HDL-C and lowered the level of the TC, LDL-C, and TG in diabetic mice and diabetic rats. These ameliorative effects may be attributed to the evidence that flavonoids can be merged into lipoproteins and chylomicrons in both the intestine and the liver and subsequently be carried within these particles. Therefore, flavonoids could protect LDL-C from oxidation [124]. Thus, flavonoid consumption was inversely related to coronary heart disease (CHD) mortality [125]. In view of these findings from previous publications, our observations that the flavonoids hesperidin and quercetin have antihyperlipidemic effects are not new, but the new thing is that the C. reticulata fruit peel hydroethanolic extract has more potent improvement effects on serum TC and LDL-C levels than either of these two flavonoids. In our opinion, the higher effects of the fruit peel hydroethanolic extract may be due to the synergistic effects of multiple constituting flavonoids in the extract as indicated by the GC-MS and HPLC analyses.

In NA/STZ-injected rats, it was explained that insulin resistance, serum insulin level, and glucose intolerance may be attributed to a significant degree by changes in the serum FFA level $[107,126]$. In the results of the current study, the diabetic rats exhibited an elevation in the serum FFA level. This elevation in the serum FFA level in diabetic rats was associated with the elevated value of HOMA-IR and the lowered values of HOMA-IS and HOMA- $\beta$ cell function. Thus, there may be a relationship between the abnormal increase in FFAs and insulin resistance as well as $\beta$-cell function. In support of this elucidation, Oh et al. [127] reported that chronic elevated levels of FFAs resulted in insulin resistance and $\beta$-cell dysfunction; therefore, the decrease in the elevated plasma FFA levels may be an important therapeutic target in both obesity and T2DM. The long-term and persistent elevation in both blood glucose and FFAs leads to $\beta$-cell glucotoxicity and lipotoxicity that in turn results in damage of $\beta$-cells as well as impairments of the surviving $\beta$-cells' secretory response to the stimulatory effects of glucose and FFAs [127-129].

Upon treatment of diabetic rats with $C$. reticulata fruit peel extract, hesperidin, and quercetin, there was a decrease in serum FFA levels, which may be implicated to the stimulation of the insulin-sensitizing effects of treatment agents and may participate to improve the effects of the tested treatments on insulin secretory response and $\beta$-cell function. These results are in concurrence with Ahmed et al.'s publication [21] which declared that administration of Citrus sinensis fruit peel hydroethanolic extract and two of its constituting flavonoids naringin and naringenin to diabetic rats caused a significant decreased effect on the elevated serum FFA level concomitant with the improvements in the tissue insulin sensitivity and $\beta$-cell insulin secretory response. Thus, the decreasing effect of the tested treatments on FFA level, in the present study, is one of mode of actions of these treatments to enhance both insulin secretion and insulin sensitivity.

Hayes et al. [130] and Mossa et al. [131] revealed that one of the indicators for liver damage and dysfunction is the elevation in the activities of AST and ALT enzymes in the serum. These enzymes are used as biochemical indicators to evaluate the degree of liver dysfunction in STZ-induced diabetic rats. Consequently, the activities of liver damage markers of ALT and AST enzymes increased in the untreated diabetic patients $[132,133]$. These data run in parallel with the results of Ahmed et al. [95] and Moneim et al. [134]. The $C$. reticulata peel hydroethanolic extract, hesperidin, and quercetin have a defensive effect against the hepatotoxicity produced by STZ-induced DM; their effects are nearly similar. In concurrence with the present study, Alam et al. [135] reported that liver functions were ameliorated in diabetic rats treated with hesperidin. Furthermore, Kobori et al. [136] reported an improvement of liver and pancreas functions by quercetin in STZ-induced diabetic mice. 
The serum levels of creatinine and urea are considered as significant biomarkers of renal dysfunction which were increased in experimentally induced diabetes [137, 138]. Renal functions are affected by DM, and the long-term complications of the renal system are collectively known as diabetic nephropathy, which occurs due to the interactions of metabolic and haemodynamic factors [139]. The results in the present study had shown a significant elevation in serum creatinine and urea levels in diabetic rats when compared to a normal control group. These results run parallel with those of Yanardağ et al. [140], Yousef et al. [141], Elbe et al. [142], and Kandemir et al. [143]. Otherwise, the treatment of the present diabetic rats with $C$. reticulata fruit peel extract, hesperidin, and quercetin caused a significant decrease in creatinine and urea levels; hesperidin was the most potent. These evidences are in accordance with the finding of Elbe et al. [142], Kandemir et al. [143], and Abdel-Raheem et al. [144], who reported that serum creatinine and urea levels significantly decreased in STZ-induced diabetic rats treated with hesperidin and quercetin. In our opinion, the amendment of the deteriorated kidney function in NA/STZinduced diabetic rats by treatments with $C$. reticulata fruit peel hydroethanolic extract, hesperidin, and quercetin may be secondary to the improvement of the diabetic conditions, suppression of oxidative stress, and enhancement of the antioxidant defense system.

Much attention has been paid to explore the role of oxidative stress, since it is widely believed that it contributes to the progress of DM and its complications [145]. Oxidative stress, which is an imbalance between formation and removal of highly reactive molecules, can lead to impaired insulin sensitivity, $\beta$-cells' dysfunction, impaired glucose tolerance, and eventually T2DM $[146,147]$. In an oxidative stress condition, ROS are responsible for lipid and protein modifications on one hand, and the overproduction of ROS in DM is a direct consequence of hyperglycemia on the other [139, 148]. Authoritative with these findings, the current study displayed an increased MDA level and lowered activities of antioxidant enzymes, viz., SOD, GPx, and GST in hepatic tissue of the STZ-induced diabetic rats [107, 147, 149-151]. The treatment of NA/STZ-induced diabetic rats in the current study with $C$. reticulata fruit peel extract, hesperidin, and quercetin produced a significant amelioration of liver levels of MDA, GSH, and antioxidant enzymes which are indicators of diminished oxidative stress via reversing the activities of these enzymatic antioxidants $[150,152,153]$. The effect of $C$. reticulata fruit peel extract on GPx activity was significantly more potent when compared with hesperidin and quercetin. These results are in accordance with Rajadurai and Prince [154] who revealed that flavonoids prevent alterations in mitochondrial lipid peroxides and enhance the activity of antioxidant enzymes (SOD, GPx, GSH, and GST) in rodents. Based on our results, it can be stated that the suppression of lipid peroxidation and enhancement of the antioxidant defense system as a result of treatments with $C$. reticulata fruit peel extract, hesperidin, and quercetin may play an important role in the amelioration of pancreatic islet histological integrity and function as well as tissue insulin sensitivity to improve the diabetic conditions in NA/STZ-induced diabetic rats.

\section{Conclusion}

In conclusion, the treatment with $C$. reticulata fruit peel hydroethanolic extract, hesperidin, and quercetin exerted antihyperglycemic and antihyperlipidemic effects which seemed to be mediated via enhancement of insulin release, insulin action, and antioxidant defense system in NA/STZinduced diabetic rats. The improved insulin release was demonstrated via the increased serum insulin and C-peptide levels in addition to the elevated calculated HOMA $\beta$-cell function, while the improvement in insulin action was manifested by the increase in HOMA-IS and a decrease in HOMA-IR in association with the elevation in mRNA expression levels of insulin receptor $\beta$-subunit, GLUT-4, and adiponectin in adipose tissues. The $C$. reticulata fruit peel hydroethanolic extract has more potent antihyperglycemic and antihypercholesterolemic effects than hesperidin and quercetin. In addition to antihyperglycemic and antihyperlipidemic effects, C. reticulata fruit peel hydroethanolic extract, hesperidin, and quercetin have potent ameliorative effects on liver and kidney functions which may be secondary to the improvements in the glycemic state, lipid profile, and antioxidant defense system. In spite of these alleviative effects in NA/STZ-induced diabetic rats, further clinical studies are required to assess the efficacy and safety of $C$. reticulata fruit peel hydroethanolic extract, hesperidin, and quercetin in type 2 diabetic human beings.

\section{Data Availability}

The data used to support the findings of this study are available from the corresponding author upon reasonable request.

\section{Conflicts of Interest}

The authors declare that they have no competing interests.

\section{Acknowledgments}

The authors acknowledged chemist Sara Sayed Zaki and Dr. Doa Sayed Abdel Gawad for performing the GC-MS and HPLC-DAD analysis in the Central Laboratory, Faculty of Postgraduate Studies for Advanced Sciences, Beni-Suef University, Egypt. The authors extend their appreciation to the Deanship of Scientific Research at King Saud University for funding the work through research group project no. RG-1436-004.

\section{Supplementary Materials}

Schematic diagram that illustrates the effect of Citrus reticulata fruit peel hydroethanolic extract, hesperidin, and quercetin on NA/STZ-induced diabetic rats. (Supplementary Materials)

\section{References}

[1] A. M. Mahmoud, O. M. Ahmed, M. B. Ashour, and A. AbdelMoneim, "In vivo and in vitro antidiabetic effects of citrus flavonoids; a study on the mechanism of action," International 
Journal of Diabetes in Developing Countries, vol. 35, no. 3, pp. 250-263, 2015.

[2] American Diabetes Association, "Diagnosis and classification of diabetes mellitus," Diabetes Care, vol. 37, Supplement_1, pp. S81-S90, 2013.

[3] American Diabetes Association, "Diagnosis and classification of diabetes mellitus," Diabetes Care, vol. 30, Suppl. 1, pp. S42S47, 2006.

[4] S. H. Wild, G. Roglic, A. Green, R. Sicree, and H. King, "Global prevalence of diabetes: estimates for the year 2000 and projections for 2030: response to rathman and giani," Diabetes Care, vol. 27, no. 10, pp. 2569-2569, 2004.

[5] D. Cheng, "Prevalence, predisposition and prevention of type II diabetes," Nutrition \& Metabolism, vol. 2, no. 1, p. 29, 2005.

[6] G. Chandramohan, S. Ignacimuthu, and K. V. Pugalendi, “A novel compound from Casearia esculenta (Roxb.) root and its effect on carbohydrate metabolism in streptozotocin-diabetic rats," European Journal of Pharmacology, vol. 590, no. 1-3, pp. 437-443, 2008.

[7] G. Saravanan and P. Ponmurugan, "Beneficial effect of Sallylcysteine (SAC) on blood glucose and pancreatic antioxidant system in streptozotocin diabetic rats," Plant Foods for Human Nutrition, vol. 65, no. 4, pp. 374-378, 2010.

[8] A. J. King, "The use of animal models in diabetes research," British Journal of Pharmacology, vol. 166, no. 3, pp. 877894, 2012.

[9] J. Y. Fang, C. H. Lin, T. H. Huang, and S. Y. Chuang, "In vivo rodent models of type 2 diabetes and their usefulness for evaluating flavonoid bioactivity," Nutrients, vol. 11, no. 3, p. 530, 2019.

[10] N. M. H. Elamin, I. M. T. Fadlalla, S. A. Omer, and H. A. M. Ibrahim, "Histopathological alteration in STZ-nicotinamide diabetic rats, a complication of diabetes or a toxicity of STZ?," International Journal of Diabetes and Clinical Research, vol. 5, no. 3, pp. 1-9, 2018.

[11] A. D. Bolzán and M. S. Bianchi, "Genotoxicity of streptozotocin," Mutation Research/Reviews in Mutation Research, vol. 512, no. 2-3, pp. 121-134, 2002.

[12] C. Kim, K. M. Newton, and R. H. Knopp, "Gestational diabetes and the incidence of type 2 diabetes: a systematic review," Diabetes Care, vol. 25, no. 10, pp. 1862-1868, 2002.

[13] G. P. S. Kumar, P. Arulselvan, D. S. Kumar, and S. P. Subramanian, "Anti-diabetic activity of fruits of Terminalia chebula on streptozotocin induced diabetic rats," Journal of Health Science, vol. 52, no. 3, pp. 283-291, 2006.

[14] J. Turk, J. A. Corbett, S. Ramanadham, A. Bohrer, and M. L. Mcdaniel, "Biochemical evidence for nitric oxide formation from streptozotocin in isolated pancreatic islets," Biochemical and Biophysical Research Communications, vol. 197, no. 3, pp. 1458-1464, 1993.

[15] D. C. Damasceno, A. O. Netto, I. L. Iessi et al., "Streptozotocin-induced diabetes models: pathophysiological mechanisms and fetal outcomes," BioMed Research International, vol. 2014, Article ID 819065, 11 pages, 2014.

[16] S. Lenzen, "The mechanisms of alloxan- and streptozotocininduced diabetes," Diabetologia, vol. 51, no. 2, pp. 216-226, 2008.

[17] C. Eleazu, K. Eleazu, S. Chukwuma, and U. Essien, "Review of the mechanism of cell death resulting from streptozotocin challenge in experimental animals, its practical use and potential risk to humans," Journal of Diabetes \& Metabolic Disorders, vol. 12, no. 1, p. 60, 2013.

[18] A. Ghasemi, S. Khalifi, and S. Jedi, "Streptozotocin-nicotinamide-induced rat model of type 2 diabetes (review)," Acta Physiologica Hungarica, vol. 101, no. 4, pp. 408-420, 2014.

[19] T. Kobayashi, K. Taguchi, T. Yasuhiro, T. Matsumoto, and K. Kamata, "Impairment of PI3-K/Akt pathway underlies attenuated endothelial function in aorta of type 2 diabetic mouse model," Hypertension, vol. 44, no. 6, pp. 956-962, 2004.

[20] A. Tahara, A. Matsuyama-Yokono, R. Nakano, Y. Someya, and M. Shibasaki, "Hypoglycaemic effects of antidiabetic drugs in streptozotocin-nicotinamide-induced mildly diabetic and streptozotocin-induced severely diabetic rats," Basic \& Clinical Pharmacology \& Toxicology, vol. 103, no. 6, pp. 560-568, 2008.

[21] O. M. Ahmed, M. A. Hassan, S. M. Abdel-Twab, and M. N. Abdel Azeem, "Navel orange peel hydroethanolic extract, naringin and naringenin have anti-diabetic potentials in type 2 diabetic rats," Biomedicine \& Pharmacotherapy, vol. 94, pp. 197-205, 2017.

[22] G. A. Birgani, A. Ahangarpour, L. Khorsandi, and H. F. Moghaddam, "Anti-diabetic effect of betulinic acid on streptozotocin-nicotinamide induced diabetic male mouse model," Brazilian Journal of Pharmaceutical Sciences, vol. 54, no. 2, 2018.

[23] S. M. Abdel Aziz, O. M. Ahmed, S. M. Abd el-Twab, H. M. alMuzafar, K. A. Amin, and M. Abdel-Gabbar, "Antihyperglycemic effects and mode of actions of Musa paradisiaca leaf and fruit peel hydroethanolic extracts in nicotinamide/streptozotocin-induced diabetic rats," Evidence-Based Complementary and Alternative Medicine, vol. 2020, Article ID 9276343, 15 pages, 2020.

[24] M. Ayyanar, K. Sankarasivaraman, and S. Ignacimuthu, "Traditional herbal medicines used for the treatment of diabetes among two major tribal groups in South Tamil Nadu, India," Ethnobotanical Leaflets, vol. 2008, no. 1, 2008276-280.

[25] S. Chen, B. H. Wu, J. B. Fang et al., "Analysis of flavonoids from lotus (Nelumbo nucifera) leaves using high performance liquid chromatography/photodiode array detector tandem electrospray ionization mass spectrometry and an extraction method optimized by orthogonal design," Journal of Chromatography A, vol. 1227, pp. 145-153, 2012.

[26] H. U. R. Mahmoud, O. M. Ahmed, H. I. Fahim, N. A. Ahmed, and M. B. Ashour, "Effects of rutin and quercetin on doxorubicin-induced renocardiotoxicity in male Wistar rats," Advances in Animal and Veterinary Sciences, vol. 8, no. 4, 2020370-384.

[27] Y. S. Huang and S. C. Ho, "Polymethoxy flavones are responsible for the anti-inflammatory activity of citrus fruit peel," Food Chemistry, vol. 119, no. 3, pp. 868-873, 2010.

[28] A. M. Rincon, A. M. Vasquez, and F. C. Padilla, "Chemical composition and bioactive compounds of flour of orange (Citrus sinensis), tangerine (Citrus reticulata) and grapefruit (Citrus paradisi) peels cultivated in Venezuela," Archivos Latinoamericanos De Nutricion, vol. 55, no. 3, pp. 305-310, 2005.

[29] C. J. Xu, P. D. Fraser, W. J. Wang, and P. M. Bramley, "Differences in the carotenoid content of ordinary citrus and lycopene-accumulating mutants," Journal of Agricultural and Food Chemistry, vol. 54, no. 15, pp. 5474-5481, 2006. 
[30] V. S. Chedea, P. Kefalas, and C. Socaciu, "Patterns of carotenoid pigments extracted from two orange peel wastes (valencia and navel var.)," Journal of Food Biochemistry, vol. 34, no. 1, pp. 101-110, 2010.

[31] K. Sharma, N. Mahato, and Y. R. Lee, "Extraction, characterization and biological activity of citrus flavonoids," Reviews in Chemical Engineering, vol. 35, no. 2, pp. 265-284, 2019.

[32] B. Levaj, V. Dragović-Uzelac, D. Bursać Kovačević, and N. Krasnići, "Determination of flavonoids in pulp and peel of mandarin fruits," Agriculturae Conspectus Scientificus, vol. 74, no. 3, pp. 221-225, 2009.

[33] M. Puri, M. L. Verma, and K. Mahale, "Processing of citrus peel for the extraction of flavonoids for biotechnological applications," in Flavonoids: Dietary Sources, Properties and Health Benefits, K. Yamane and Y. Kato, Eds., pp. 1-17, Nova Science Publishers, 2012.

[34] R. P. Constantin, R. P. Constantin, A. Bracht, N. S. Yamamoto, E. L. Ishii-Iwamoto, and J. Constantin, "Molecular mechanisms of citrus flavanones on hepatic gluconeogenesis," Fitoterapia, vol. 92, pp. 148-162, 2014.

[35] H. Parhiz, A. Roohbakhsh, F. Soltani, R. Rezaee, and M. Iranshahi, "Antioxidant and anti-inflammatory properties of the citrus flavonoids hesperidin and hesperetin: an updated review of their molecular mechanisms and experimental models," Phytotherapy Research, vol. 29, no. 3, pp. 323-331, 2015.

[36] M. Bule, A. Abdurahman, S. Nikfar, M. Abdollahi, and M. Amini, "Antidiabetic effect of quercetin: a systematic review and meta-analysis of animal studies," Food and Chemical Toxicology, vol. 125, pp. 494-502, 2019.

[37] O. M. Ahmed, A. A. Ahmed, H. I. Fahim, and M. Y. Zaky, "Quercetin and naringenin abate diethylnitrosamine/acetylaminofluorene-induced hepatocarcinogenesis in Wistar rats: the roles of oxidative stress, inflammation and cell apoptosis," Drug and Chemical Toxicology, pp. 1-12, 2019.

[38] A. B. Bentz, "A review of quercetin: chemistry, antioxidant properties, and bioavailability," Journal of Young Investigators, vol. 19, no. 10, pp. 1-8, 2009.

[39] G. Negri, D. de Santi, and R. Tabach, "Chemical composition of hydroethanolic extracts from Siparuna guianensis, medicinal plant used as anxiolytics in Amazon region," Revista Brasileira de Farmacognosia, vol. 22, no. 5, pp. 1024-1034, 2012.

[40] O. M. Ahmed, "Antihyperglycemic effects of water extract of Ulva lactuca and its polysaccharides in nicotinamidestreptozotocin-induced diabetic rats," Journal-Egyptian German Society of Zoology, vol. 1, no. 54, pp. 273-297, 2010.

[41] T. K. Lim, "Citrus reticulata," in Edible Medicinal and Nonmedicinal Plants, pp. 695-720, Springer, 2012.

[42] J. Kakadiya, H. Mulani, and N. Shah, "Protective effect of hesperidin on cardiovascular complication in experimentally induced myocardial infarction in diabetes in rats," Journal of Basic and Clinical Pharmacy (JBCP), vol. 1, no. 2, pp. 8591, 2010.

[43] S. H. Abdel-Azeim, A. M. Hassan, N. S. Hassan, S. E. Aly, and M. A. Abdel-Wahhab, "Quercetin inhibits the cytotoxicity and oxidative stress in liver of rats fed aflatoxincontaminated diet," Toxicology Reports, vol. 1, pp. 319-329, 2014.

[44] P. Trinder, "Determination of glucose in blood using glucose oxidase with an alternative oxygen acceptor," Annals of Clinical Biochemistry, vol. 6, no. 1, pp. 24-27, 1969.
[45] J. R. Baker, P. A. Metcalf, R. N. Johnson, D. Newman, and P. Rietz, "Use of protein-based standards in automated colorimetric determinations of fructosamine in serum," Clinical Chemistry, vol. 31, no. 9, pp. 1550-1554, 1985.

[46] J. S. Mishra, A. S. More, and S. Kumar, "Elevated androgen levels induce hyperinsulinemia through increase in Ins1 transcription in pancreatic beta cells in female rats," Biology of Reproduction, vol. 98, no. 4, pp. 520-531, 2018.

[47] A. B. M. Aref, O. M. Ahmed, L. A. Ali, and M. Semmler, "Maternal rat diabetes mellitus deleteriously affects insulin sensitivity and beta-cell function in the offspring," Journal of Diabetes Research, vol. 2013, Article ID 429154, 10 pages, 2013.

[48] C. C. Allain, L. S. Poon, C. S. G. Chan, W. Richmond, and P. C. Fu, "Enzymatic determination of total serum cholesterol," Clinical Chemistry, vol. 20, no. 4, pp. 470-475, 1974

[49] P. R. Finley and N. W. Tietz, Tietz Clinical Guide to Laboratory Tests, WB Saunders Company, Philadelphia, 1996.

[50] W. T. Friedewald, R. I. Levy, and D. S. Fredrickson, "Estimation of the concentration of low-density lipoprotein cholesterol in plasma, without use of the preparative ultracentrifuge," Clinical Chemistry, vol. 18, no. 6, pp. 499$502,1972$.

[51] W. T. Norbert, Clinical guide to laboratory tests, W. B. Saunders Company, Philadelphia, 1995.

[52] W. G. Duncombe, "The colorimetric micro-determination of long-chain fatty acids," Biochemical Journal, vol. 88 , no. 1 , pp. 7-10, 1963.

[53] F. J. Gella, T. Olivella, M. C. Pastor et al., “A simple procedure for the routine determination of aspartate aminotransferase and alanine aminotransferase with pyridoxal phosphate," Clinica Chimica Acta, vol. 153, no. 3, pp. 241-247, 1985.

[54] D. L. Fabiny and G. Ertingshausen, "Automated reaction-rate method for determination of serum creatinine with the CentrifiChem," Clinical Chemistry, vol. 17, no. 8, pp. 696-700, 1971.

[55] A. Tabacco, F. Meiattini, E. Moda, and P. Tarli, "Simplified enzymic/colorimetric serum urea nitrogen determination," Clinical Chemistry, vol. 25, no. 2, pp. 336-337, 1979.

[56] S. Seifter, S. Dayton, B. Novic, and E. Muntwyler, "The estimation of glycogen with the anthrone reagent," Archives of Biochemistry and Biophysics, vol. 25, no. 1, pp. 191-200, 1950.

[57] S. M. H. Kabir and R. Begum, Toxicity of Three Organophosphorus Insecticides to Singhi Fish Heteropneustes fossilis (Bloch), vol. 26, The Dhaka University Studies. Part B, 1978.

[58] W. Stalmans and H. G. Hers, "The stimulation of liver phosphorylase B by AMP, fluoride and sulfate," The FEBS Journal, vol. 54, no. 2, pp. 341-350, 1975.

[59] H. G. Preuss, S. T. Jarrell, R. Scheckenbach, S. Lieberman, and R. A. Anderson, "Comparative effects of chromium, vanadium and Gymnema sylvestre on sugar-induced blood pressure elevations in SHR," Journal of the American College of Nutrition, vol. 17, no. 2, pp. 116-123, 1998.

[60] E. Beutler, O. Duron, and B. M. Kelly, "Improved method for determination of blood glutathione," The Journal of Laboratory and Clinical Medicine, vol. 61, no. 5, pp. 882-888, 1963.

[61] B. Matkovics, M. Kotorman, I. S. Varga, D. Q. Hai, and C. S. Varga, "Oxidative stress in experimental diabetes induced by streptozotocin,” Acta Physiologica Hungarica, vol. 85, pp. 2938, 1997. 
[62] B. Mannervik and C. Guthenberg, "[28] Glutathione transferase (human placenta)," Methods in Enzymology, vol. 77, pp. 231-235, 1981.

[63] S. Marklund and G. Marklund, "Involvement of the superoxide anion radical in the autoxidation of pyrogallol and a convenient assay for superoxide dismutase," The FEBS Journal, vol. 47, no. 3, pp. 469-474, 1974.

[64] J. D. Bancroft and A. Stevens, Theory and Practice of Histological Techniques, Churchill Livingstone, Edinburgh, 2nd ed. edition, 1982.

[65] P. Chomzynski and N. Sacchi, "Single-step method of RNA isolation by acid guanidinium thiocyanate-phenolchloroform extraction," Analytical Biochemistry, vol. 162, no. 1, pp. 156-159, 1987.

[66] R. Boom, C. J. Sol, M. M. Salimans, C. L. Jansen, P. M. Wertheim-van Dillen, and J. van der Noordaa, "Rapid and simple method for purification of nucleic acids," Journal of Clinical Microbiology, vol. 28, no. 3, pp. 495-503, 1990.

[67] J. Sambrook and D. W. Russell, Molecular Cloning Laboratory Manual, Chemical Industry Press, Beijing, 5th ed. edition, 2008.

[68] J. E. Caminos, R. Nogueiras, R. Gallego et al., "Expression and regulation of adiponectin and receptor in human and rat placenta," The Journal of Clinical Endocrinology \& Metabolism, vol. 90, no. 7, pp. 4276-4286, 2005.

[69] T. Limin, X. Hou, J. Liu et al., "Chronic ethanol consumption resulting in the downregulation of insulin receptor- $\beta$ subunit, insulin receptor substrate-1, and glucose transporter 4 expression in rat cardiac muscles," Alcohol, vol. 43, no. 1, pp. 51-58, 2009.

[70] M. A. Vazquez Prieto, A. Bettaieb, C. Rodriguez Lanzi et al., "Catechin and quercetin attenuate adipose inflammation in fructose-fed rats and 3T3-L1 adipocytes," Molecular Nutrition \& Food Research, vol. 59, no. 4, pp. 622-633, 2015.

[71] M. Roa, K. Blane, and M. Zonneberg, One Way Analysis of Variance. Version IA (C), PC-STAT, Program coded by University of Georgia, USA, 1985.

[72] American Diabetes Association, "Diagnosis and classification of diabetes mellitus," Diabetes Care, vol. 33, Suppl 1, pp. S62S69, 2009.

[73] American Diabetes Association, "Report of the expert committee on the diagnosis and classification of diabetes mellitus," Diabetes Care, vol. 38, pp. S8-S16, 2014.

[74] R. A. DeFronzo, E. Ferrannini, L. Groop et al., "Type 2 diabetes mellitus," Nature Reviews Disease Primers, vol. 1, article 15019, pp. 1-22, 2015.

[75] B. Giri, S. Dey, T. Das, M. Sarkar, J. Banerjee, and S. K. Dash, "Chronic hyperglycemia mediated physiological alteration and metabolic distortion leads to organ dysfunction, infection, cancer progression and other pathophysiological consequences: an update on glucose toxicity," Biomedicine \& Pharmacotherapy, vol. 107, pp. 306-328, 2018.

[76] P. Palsamy and S. Subramanian, "Resveratrol, a natural phytoalexin, normalizes hyperglycemia in streptozotocinnicotinamide induced experimental diabetic rats," Biomedicine \& Pharmacotherapy, vol. 62, no. 9, pp. 598-605, 2008.

[77] T. Szkudelski, "Streptozotocin-nicotinamide-induced diabetes in the rat. Characteristics of the experimental model," Experimental Biology and Medicine, vol. 237, no. 5, pp. 481-490, 2012.
[78] N. Ziamajidi, S. Khaghani, G. Hassanzadeh et al., "Amelioration by chicory seed extract of diabetes- and oleic acidinduced non-alcoholic fatty liver disease (NAFLD)/non-alcoholic steatohepatitis (NASH) via modulation of PPAR $\alpha$ and SREBP-1," Food and Chemical Toxicology, vol. 58, pp. 198209, 2013.

[79] M. Asrafuzzaman, Y. Cao, R. Afroz, D. Kamato, S. Gray, and P. J. Little, "Animal models for assessing the impact of natural products on the aetiology and metabolic pathophysiology of type 2 diabetes," Biomedicine \& Pharmacotherapy, vol. 89, pp. 1242-1251, 2017.

[80] N. Ziamajidi, A. Nasiri, R. Abbasalipourkabir, and S. Sadeghi Moheb, "Effects of garlic extract on TNF- $\alpha$ expression and oxidative stress status in the kidneys of rats with STZ + nicotinamide-induced diabetes," Pharmaceutical Biology, vol. 55, no. 1, pp. 526-531, 2016.

[81] T. Szkudelski, "The mechanism of alloxan and streptozotocin action in B cells of the rat pancreas," Physiological Research, vol. 50, no. 6, pp. 537-546, 2001.

[82] M. J. Kim, G. R. Ryu, J. S. Chung et al., "Protective effects of epicatechin against the toxic effects of streptozotocin on rat pancreatic islets: in vivo and in vitro," Pancreas, vol. 26, no. 3, pp. 292-299, 2003.

[83] L. Zhang, J. Yang, X. Q. Chen et al., “Antidiabetic and antioxidant effects of extracts from Potentilla discolor Bunge on diabetic rats induced by high fat diet and streptozotocin," Journal of Ethnopharmacology, vol. 132, no. 2, pp. 518-524, 2010.

[84] L. Pari and S. Suman, "Antihyperglycemic and antilipidperoxidative effects of flavanoid naringin in streptozotocinnicotinamide induced diabetic rats," International Journal Of Biological and Medical Research, vol. 1, no. 4, pp. 206210, 2010.

[85] F. Hajiaghaalipour, M. Khalilpourfarshbafi, and A. Arya, "Modulation of glucose transporter protein by dietary flavonoids in type 2 diabetes mellitus," International Journal of Biological Sciences, vol. 11, no. 5, pp. 508-524, 2015.

[86] R. Vinayagam and B. Xu, "Antidiabetic properties of dietary flavonoids: a cellular mechanism review," Nutrition \& Metabolism, vol. 12, no. 1, 2015.

[87] P. Vijay and S. Vimukta, "The role of natural antioxidants in oxidative stress induced diabetes mellitus," Research Journal of Pharmaceutical Science, vol. 3, no. 4, pp. 1-6, 2014.

[88] A. Mohammed, Antioxidative and Antidiabetic Effects of Some African Medicinal Plants, University of KwaZulu-Natal, Durban, 2016.

[89] J. Żuchowski, Ł. Pecio, and A. Stochmal, "Novel flavonol glycosides from the aerial parts of lentil (Lens culinaris)," Molecules, vol. 19, no. 11, pp. 18152-18178, 2014.

[90] P. Pushparaj, C. H. Tan, and B. K. H. Tan, "Effects of Averrhoa bilimbi leaf extract on blood glucose and lipids in streptozotocin-diabetic rats," Journal of Ethnopharmacology, vol. 72, no. 1-2, pp. 69-76, 2000.

[91] J. Li, F. Gong, and F. Li, "Hypoglycemic and hypolipidemic effects of flavonoids from tatary buckwheat in type 2 diabetic rats," Biomedical Research, vol. 27, no. 1, pp. 132-137, 2016.

[92] M. Vessal, M. Hemmati, and M. Vasei, "Antidiabetic effects of quercetin in streptozocin-induced diabetic rats," Comparative Biochemistry and Physiology Part C: Toxicology \& Pharmacology, vol. 135, no. 3, pp. 357-364, 2003. 
[93] P. N. Pushparaj, H. K. Low, J. Manikandan, B. K. H. Tan, and C. H. Tan, "Anti-diabetic effects of Cichorium intybus in streptozotocin-induced diabetic rats," Journal of Ethnopharmacology, vol. 111, no. 2, pp. 430-434, 2007.

[94] M. Schaalan, H. S. el-Abhar, M. Barakat, and E. S. el-Denshary, "Westernized-like-diet-fed rats: effect on glucose homeostasis, lipid profile, and adipocyte hormones and their modulation by rosiglitazone and glimepiride," Journal of Diabetes and its Complications, vol. 23, no. 3, pp. 199-208, 2009.

[95] O. M. Ahmed, A. M. Mahmoud, A. Abdel-Moneim, and M. B. Ashour, "Antidiabetic effects of hesperidin and naringin in type 2 diabetic rats," Diabetologia Croatica, vol. 41, no. 2, pp. 53-67, 2012.

[96] N. M. Kamal, Role of hormone receptor in the etiology of insulin dependent and non-insulin dependent diabetes mellitus. Master in Clinical and Chemical Pathology Thesis, Faculty of Medicine, Cairo University, 1991.

[97] A. C. Powers, "Chapter 323. Diabetes mellitus," in Harrison's Principles of Internal Medicine, D. L. Kasper, A. S. Fauci, and D. L. Longo, Eds., The McGraw Companies, Inc., 16th ed. edition, 2005.

[98] O. M. Ahmed, "Antihyperglycemic effects of water extract of Ulva lactuca and its polysaccharides in nicotinamidestreptozotocin diabetic rats," Egyptian Journal of Zoology, vol. 54, pp. 273-297, 2010.

[99] H. Beck-Nielsen, "Insulin resistance: organ manifestations and cellular mechanisms," Ugeskrift for Laeger, vol. 164, no. 16 , pp. 2130-2135, 2002.

[100] A. H. Gold, "The effect of diabetes and insulin on liver glycogen synthetase activation," Journal of Biological Chemistry, vol. 245, no. 4, pp. 903-905, 1970.

[101] J. Raju, D. Gupta, A. R. Rao, P. K. Yadava, and N. Z. Baquer, "Trigonella foenum graecum (fenugreek) seed powder improves glucose homeostasis in alloxan diabetic rat tissues by reversing the altered glycolytic, gluconeogenic and lipogenic enzymes," Molecular and Cellular Biochemistry, vol. 224, no. 1/2, pp. 45-51, 2001.

[102] U. J. Jung, M. K. Lee, K. S. Jeong, and M. S. Choi, “The hypoglycemic effects of hesperidin and naringin are partly mediated by hepatic glucose-regulating enzymes in C57BL/KsJ$\mathrm{db} / \mathrm{db}$ mice," The Journal of Nutrition, vol. 134, no. 10, pp. 2499-2503, 2004.

[103] B. K. Chakravarthy, S. Gupta, and K. D. Gode, "Antidiabetic effect of (-)-epicatechin," The Lancet, vol. 320, no. 8292, pp. 272-273, 1982.

[104] B. K. Chakravarthy, S. Gupta, and K. D. Gode, "Functional beta cell regeneration in the islets of pancreas in alloxan induced diabetic rats by (-)-epicatechin," Life Sciences, vol. 31, no. 24, pp. 2693-2697, 1982.

[105] B. Sharma, C. Balomajumder, and P. Roy, "Hypoglycemic and hypolipidemic effects of flavonoid rich extract from Eugenia jambolana seeds on streptozotocin induced diabetic rats," Food and Chemical Toxicology, vol. 46, no. 7, pp. 23762383, 2008.

[106] R. Pandit, A. Phadke, and A. Jagtap, “Antidiabetic effect of Ficus religiosa extract in streptozotocin-induced diabetic rats," Journal of Ethnopharmacology, vol. 128, no. 2, pp. 462-466, 2010.

[107] R. Kapoor and P. Kakkar, "Naringenin accords hepatoprotection from streptozotocin induced diabetes in vivo by modulating mitochondrial dysfunction and apoptotic sig- naling cascade," Toxicology Reports, vol. 1, pp. 569-581, 2014.

[108] R. K. AL-Ishaq, M. Abotaleb, P. Kubatka, K. Kajo, and D. Büsselberg, "Flavonoids and their anti-diabetic effects: cellular mechanisms and effects to improve blood sugar levels," Biomolecules, vol. 9, no. 430, pp. 1-35, 2019.

[109] T. M. Wallace, J. C. Levy, and D. R. Matthews, "Use and abuse of HOMA modeling," Diabetes Care, vol. 27, no. 6, pp. 1487-1495, 2004.

[110] H. Ruan and L. Q. Dong, "Adiponectin signaling and function in insulin target tissues," Journal of Molecular Cell Biology, vol. 8, no. 2, pp. 101-109, 2016.

[111] T. Yamauchi, J. Kamon, H. Waki et al., "The fat-derived hormone adiponectin reverses insulin resistance associated with both lipoatrophy and obesity," Nature Medicine, vol. 7, no. 8, pp. 941-946, 2001.

[112] O. M. Ahmed, A. A. Moneim, I. A. Yazid, and A. M. Mahmoud, "Antihyperglycemic, antihyperlipidemic and antioxidant effects and the probable mechanisms of action of Ruta graveolens infusion and rutin in nicotinamidestreptozotocin-induced diabetic rats," Diabetologia Croatica, vol. 39, no. 1, pp. 15-35, 2010.

[113] N. Morral, "Novel targets and therapeutic strategies for type 2 diabetes," Trends in Endocrinology \& Metabolism, vol. 14, no. 4, pp. 169-175, 2003.

[114] O. M. Ahmed, "The hypoglycemic effect of curcumin and esculetin and their probable mechanisms of action in streptozotocin diabetic albino rats," Journal-Egyptian German Society of Zoology, vol. 46, no. A, pp. 351-375, 2005.

[115] J. Cadefau, M. Bollen, and W. Stalmans, "Glucose-induced glycogenesis in the liver involves the glucose-6-phosphatedependent dephosphorylation of glycogen synthase," Biochemical Journal, vol. 322, no. 3, pp. 745-750, 1997.

[116] U. J. Jung, M. K. Lee, Y. B. Park, M. A. Kang, and M. S. Choi, "Effect of citrus flavonoids on lipid metabolism and glucoseregulating enzyme mRNA levels in type-2 diabetic mice," The International Journal of Biochemistry \& Cell Biology, vol. 38, no. 7, pp. 1134-1145, 2006.

[117] H. Eid and P. Haddad, "The antidiabetic potential of quercetin: underlying mechanisms," Current Medicinal Chemistry, vol. 24, no. 4, pp. 355-364, 2017.

[118] O. Ulicna, K. Volkovová, and B. Istvánová, “Bioenergetics of liver mitochondria in rats in experimental insulin-dependent diabetes," Bratislavske Lekarske Listy, vol. 97, no. 10, pp. 619624, 1996.

[119] K. M. Wasan, S. P. Ng, W. Wong, and B. B. Rodrigues, “Streptozotocin and alloxan-induced diabetes modifies total plasma and lipoprotein lipid concentration and composition without altering cholesteryl ester transfer activity," Basic \& Clinical Pharmacology \& Toxicology, vol. 83, no. 4, pp. 169-175, 1998.

[120] B. Wittenstein, M. Klein, B. Finckh, K. Ullrich, and A. Kohlschütter, "Plasma antioxidants in pediatric patients with glycogen storage disease, diabetes mellitus, and hypercholesterolemia," Free Radical Biology and Medicine, vol. 33, no. 1, pp. 103-110, 2002.

[121] A. K. Singh and J. Singh, "Evaluation of anti-diabetic potential of leaves and stem of Flacourtia jangomas in streptozotocin-induced diabetic rats," Indian Journal of Pharmacology, vol. 42, no. 5, pp. 301-305, 2010.

[122] S. Gorinstein, O. J. M. Vargas, N. O. Jaramillo et al., "The total polyphenols and the antioxidant potentials of some 
selected cereals and pseudocereals," European Food Research and Technology, vol. 225, no. 3-4, pp. 321-328, 2007.

[123] T. Zhou, D. Luo, X. Li, and Y. Luo, "Hypoglycemic and hypolipidemic effects of flavonoids from lotus (Nelumbo nuficera gaertn) leaf in diabetic mice," Journal of Medicinal Plants Research, vol. 3, no. 4, pp. 290-293, 2009.

[124] A. N. Khan, R. A. Khan, M. Ahmad, and N. Mushtaq, "Role of antioxidant in oxidative stress and diabetes mellitus," Journal of Pharmacognosy and Phytochemistry, vol. 3, no. 6, pp. 217-220, 2015.

[125] M. Sugiura, M. Ohshima, K. Ogawa, and M. Yano, "Chronic administration of satsuma mandarin fruit (Citrus unshiu MARC.) improves oxidative stress in streptozotocininduced diabetic rat liver," Biological and Pharmaceutical Bulletin, vol. 29, no. 3, pp. 588-591, 2006.

[126] M. F. Mahmoud, N. A. Hassan, H. M. El Bassossy, and A. Fahmy, "Quercetin protects against diabetes-induced exaggerated vasoconstriction in rats: effect on low grade inflammation," Plos One, vol. 8, no. 5, p. e63784, 2013.

[127] Y. S. Oh, G. D. Bae, D. J. Baek, E. Y. Park, and H. S. Jun, "Fatty acid-induced lipotoxicity in pancreatic beta-cells during development of type 2 diabetes," Frontiers in Endocrinology, vol. 9, no. 384, 2018.

[128] K. Kupsal, S. Mudigonda, K. K. Gundapaneni, M. A. Tupurani, R. K. Galimudi, and V. S. Nyayapathi, "Glucotoxicity and lipotoxicity induced beta-cell apoptosis in type 2 diabetes mellitus," International Journal of Analytical Bio-Science, vol. 3, no. 4, pp. 84-89, 2015.

[129] G. I. Shulman, "Cellular mechanisms of insulin resistance," Journal of Clinical Investigation, vol. 106, no. 2, pp. 171$176,2000$.

[130] R. B. Hayes, A. Sheffet, and R. Spirtas, "Cancer mortality among a cohort of chromium pigment workers," American Journal of Industrial Medicine, vol. 16, no. 2, pp. 127-133, 1989.

[131] A. T. H. Mossa, A. A. Refaie, A. Ramadan, and J. Bouajila, "Amelioration of prallethrin-induced oxidative stress and hepatotoxicity in rat by the administration of Origanum majorana essential oil," BioMed Research International, vol. 2013, Article ID 859085, 11 pages, 2013.

[132] P. E. T. Arkkila, P. J. Koskinen, I. M. Kantola, T. Rönnemaa, E. Seppänen, and J. S. Viikari, "Diabetic complications are associated with liver enzyme activities in people with type 1 diabetes," Diabetes Research and Clinical Practice, vol. 52, no. 2, pp. 113-118, 2001.

[133] U. S. Adiga and B. N. Malawadi, "Association of diabetic nephropathy and liver disorders," Journal of Clinical and Diagnostic Research, vol. 10, no. 10, pp. BC05-BC07, 2016.

[134] A. A. Moneim, S. M. Abd El-Twab, M. B. Ashour, and A. I. Yousef, "Hepato-renal protective effects of gallic acid and pcoumaric acid in nicotinamide/streptozotocin-induced diabetic rats," International Journal of Bioassays, vol. 5, no. 6, pp. 4641-4649, 2016.

[135] M. A. Alam, N. Subhan, M. M. Rahman, S. J. Uddin, H. M. Reza, and S. D. Sarker, "Effect of citrus flavonoids, naringin and naringenin, on metabolic syndrome and their mechanisms of action," Advances in Nutrition, vol. 5, no. 4, pp. 404-417, 2014.

[136] M. Kobori, S. Masumoto, Y. Akimoto, and Y. Takahashi, "Dietary quercetin alleviates diabetic symptoms and reduces streptozotocin-induced disturbance of hepatic gene expres- sion in mice," Molecular Nutrition \& Food Research, vol. 53, no. 7, pp. 859-868, 2009.

[137] S. Sivakumar, P. Palsamy, and S. P. Subramanian, "Impact of D-pinitol on the attenuation of proinflammatory cytokines, hyperglycemia-mediated oxidative stress and protection of kidney tissue ultrastructure in streptozotocin-induced diabetic rats," Chemico-Biological Interactions, vol. 188, no. 1, pp. 237-245, 2010.

[138] B. H. Ali, I. al-Husseni, S. Beegam et al., "Effect of gum arabic on oxidative stress and inflammation in adenine-induced chronic renal failure in rats," PloS One, vol. 8, no. 2, p. e55242, 2013.

[139] O. U. Akpan, D. E. Ikpi, and B. E. Etim, "Ocimum gratissimum alleviates derangements in serum and biliary bilirubin, cholesterol and electrolytes in streptozotocin-induced diabetic rats," International Journal of Biochemistry Research \& Review, vol. 3, no. 3, pp. 171-189, 2013.

[140] R. Yanardağ, Ş. Bolkent, Ö. Özsoy-Saçan, and Ö. KarabulutBulan, "The effects of chard (Beta vulgaris L. var. cicla) extract on the kidney tissue, serum urea and creatinine levels of diabetic rats," Phytotherapy Research, vol. 16, no. 8, pp. 758-761, 2002.

[141] M. I. Yousef, S. A. M. Omar, M. I. el-Guendi, and L. A. Abdelmegid, "Potential protective effects of quercetin and curcumin on paracetamol-induced histological changes, oxidative stress, impaired liver and kidney functions and haematotoxicity in rat," Food and Chemical Toxicology, vol. 48, no. 11, pp. 3246-3261, 2010.

[142] H. Elbe, N. Vardi, M. Esrefoglu, B. Ates, S. Yologlu, and C. Taskapan, "Amelioration of streptozotocin-induced diabetic nephropathy by melatonin, quercetin, and resveratrol in rats," Human \& Experimental Toxicology, vol. 34, no. 1, pp. 100-113, 2014.

[143] F. M. Kandemir, M. Ozkaraca, S. Küçükler, C. Caglayan, and B. Hanedan, "Preventive effects of hesperidin on diabetic nephropathy induced by streptozotocin via modulating TGF- $\beta 1$ and oxidative DNA damage," Toxin Reviews, vol. 37, no. 4, pp. 287-293, 2017.

[144] I. T. Abdel-Raheem, A. A. Abdel-Ghany, and G. A. Mohamed, "Protective effect of quercetin against gentamicin-induced nephrotoxicity in rats," Biological and Pharmaceutical Bulletin, vol. 32, no. 1, pp. 61-67, 2009.

[145] A. C. Maritim, R. A. Sanders, and J. B. Watkins, "Diabetes, oxidative stress, and antioxidants: a review," Journal of biochemical and molecular toxicology, vol. 17, no. 1, pp. 24-38, 2003.

[146] I. C. West, "Radicals and oxidative stress in diabetes," Diabetic Medicine, vol. 17, no. 3, pp. 171-180, 2000.

[147] M. Banerjee and P. Vats, "Reactive metabolites and antioxidant gene polymorphisms in type 2 diabetes mellitus," Redox Biology, vol. 2, pp. 170-177, 2014.

[148] A. Kassab and A. Piwowar, "Cell oxidant stress delivery and cell dysfunction onset in type 2 diabetes," Biochimie, vol. 94, no. 9, pp. 1837-1848, 2012.

[149] P. R. Ling, C. Mueller, R. J. Smith, and B. R. Bistrian, "Hyperglycemia induced by glucose infusion causes hepatic oxidative stress and systemic inflammation, but not STAT3 or MAP kinase activation in liver in rats," Metabolism, vol. 52, no. 7, pp. 868-874, 2003.

[150] A. M. Mahmoud, M. B. Ashour, A. Abdel-Moneim, and O. M. Ahmed, "Hesperidin and naringin attenuate 
hyperglycemia-mediated oxidative stress and proinflammatory cytokine production in high fat fed/streptozotocininduced type 2 diabetic rats," Journal of Diabetes and Its Complications, vol. 26, no. 6, pp. 483-490, 2012.

[151] W. Zhang, J. Zhao, J. Wang et al., "Hypoglycemic effect of aqueous extract of seabuckthorn (Hippophae rhamnoides L.) seed residues in streptozotocin-induced diabetic rats," Phytotherapy Research, vol. 24, no. 2, pp. n/a-232, 2009.

[152] S. J. Padayatty, A. Katz, Y. Wang et al., "Vitamin C as an antioxidant: evaluation of its role in disease prevention," Journal of the American College of Nutrition, vol. 22, no. 1, pp. 18-35, 2003.

[153] S. V. Reddy, A. K. Tiwari, U. S. Kumar, R. J. Rao, and J. M. Rao, "Free radical scavenging, enzyme inhibitory constituents from antidiabetic Ayurvedic medicinal plant Hydnocarpus wightiana Blume," Phytotherapy Research, vol. 19, no. 4, pp. 277-281, 2005.

[154] M. Rajadurai and P. S. M. Prince, "Naringin ameliorates mitochondrial lipid peroxides, antioxidants and lipids in iso-proterenol-induced myocardial infarction in Wistar rats," Phytotherapy Research, vol. 23, no. 3, pp. 358-362, 2009. 